\title{
Nebulin nemaline myopathy recapitulated in a compound heterozygous mouse model with both a missense and a nonsense mutation in Neb
}

Jenni M. Laitila ${ }^{1,2,3^{*}}$ D, Elyshia L. McNamara ${ }^{3,4}$, Catherine D. Wingate ${ }^{5}$, Hayley Goullee ${ }^{3,4}$, Jacob A. Ross ${ }^{6}$, Rhonda L. Taylor ${ }^{3,4}$, Robbert van der Pijl 7 , Lisa M. Griffiths' ${ }^{8}$, Rachel Harries ${ }^{3,4}$, Gianina Ravenscroft ${ }^{3,4}$, Joshua S. Clayton ${ }^{3,4}$, Caroline Sewry ${ }^{9,10}$, Michael W. Lawlor ${ }^{11}$, Coen A. C. Ottenheijm ${ }^{7}$ Anthony J. Bakker ${ }^{5}$, Julien Ochala ${ }^{6}$, Nigel G. Laing ${ }^{3,4}$, Carina Wallgren-Pettersson ${ }^{1,2}$, Katarina Pelin ${ }^{1,2,12}$ and Kristen J. Nowak $k^{3,13,14}$

\begin{abstract}
Nemaline myopathy (NM) caused by mutations in the gene encoding nebulin (NEB) accounts for at least $50 \%$ of all NM cases worldwide, representing a significant disease burden. Most NEB-NM patients have autosomal recessive disease due to a compound heterozygous genotype. Of the few murine models developed for NEB-NM, most are Neb knockout models rather than harbouring Neb mutations. Additionally, some models have a very severe phenotype that limits their application for evaluating disease progression and potential therapies. No existing murine models possess compound heterozygous Neb mutations that reflect the genotype and resulting phenotype present in most patients. We aimed to develop a murine model that more closely matched the underlying genetics of NEB-NM, which could assist elucidation of the pathogenetic mechanisms underlying the disease. Here, we have characterised a mouse strain with compound heterozygous Neb mutations; one missense (p.Tyr2303His), affecting a conserved actin-binding site and one nonsense mutation (p.Tyr935*), introducing a premature stop codon early in

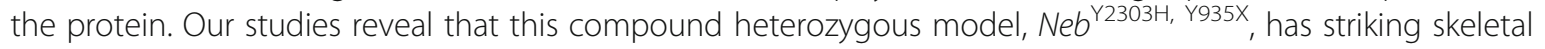
muscle pathology including nemaline bodies. In vitro whole muscle and single myofibre physiology studies also demonstrate functional perturbations. However, no reduction in lifespan was noted. Therefore, Neb ${ }^{\text {Y2303H,Y935X mice }}$ recapitulate human NEB-NM and are a much needed addition to the NEB-NM mouse model collection. The moderate phenotype also makes this an appropriate model for studying NEB-NM pathogenesis, and could potentially be suitable for testing therapeutic applications.
\end{abstract}

Keywords: Nebulin, Murine model, Nemaline myopathy, Skeletal muscle, Neuromuscular disease, Congenital myopathy

\section{Introduction}

Nemaline myopathy (NM) is one of the most common congenital myopathies and is caused by pathogenic variants in one of at least twelve different genes [4, 18, 27, $29,37,52,55,64,69,74,75,91]$. Patient muscle biopsies

\footnotetext{
*Correspondence: jenni.laitila@helsinki.fi

${ }^{1}$ Folkhälsan Institute of Genetics, Folkhälsan Research Center, Biomedicum, Helsinki, Finland

${ }^{2}$ Department of Medical and Clinical Genetics, Medicum, University of Helsinki, Helsinki, Finland

Full list of author information is available at the end of the article
}

show accumulation of Z-disc and thin filament associated proteins into aggregates called nemaline bodies, usually accompanied by disorganization of the muscle $\mathrm{Z}$ discs $[14,80,83]$. There can be large variation in clinical severity, from in utero presentation and early neonatal death, through to milder forms with later onset $[77,86]$.

Autosomal recessive NM is most commonly caused by pathogenic variants in the nebulin gene (NEB; NEM2, Online Mendelian Inheritance in Man \#256030) [44]. While the clinical severity varies from severe, early onset 
forms through to milder forms, NEB-NM most often presents as a slowly progressive disease, with weakness in proximal skeletal muscles and potential later involvement of distal muscles [77]. Appropriate respiratory management usually results in a normal lifespan [73]. To date, over $200 \mathrm{NM}$-causing pathogenic variants have been identified throughout the entire length of $N E B$ [32, $44,64,65]$. Variants in $N E B$ can also cause disorders described as distal nebulin myopathy [84], distal NM [45], foetal akinesia/lethal multiple pterygium syndrome $[1$, $44]$ and, in rare cases, core-rod myopathy [71].

$N E B$ is comprised of 183 exons that encode a theoretical $26 \mathrm{~kb}$ full-length mRNA, although extensive alternative splicing results in a wide variety of different transcripts $[19,38]$. Nebulin is a giant $(600-900 \mathrm{kDa})$ actin-binding protein, with the $\mathrm{C}$-terminus located deep within the $\mathrm{Z}$ disc whilst the rest of the protein stretches nearly the entire length of the thin filament of the skeletal muscle sarcomere [36]. It is thought to stabilise, stiffen and strengthen actin filaments, specify minimum thin-filament length as well as regulate Z-disc width and intermyofibrillar connectivity through its interaction with multiple proteins, e.g. desmin, titin and myopalladin $[8,13,31,34,62$, $81,89]$. Recently it has also been shown that nebulin contributes to thin filament activation and cross-bridge recruitment [34]. Although these multiple roles for nebulin have been suggested, many known and potential aspects of its function are still to be understood. For example, the dynamic movement of nebulin and its interaction partners in the thin filament during muscle contraction remains unclear $[13,88]$. Furthermore, the nebulin transcript is alternatively spliced to produce alternative protein isoforms (for example super repeat S21 in isoforms a and b; see our recent report [40]). The functional importance of the different isoforms is currently under investigation.

Despite the large number of pathogenic variants identified in $N E B$, no clear mutational hotspots or genotypephenotype correlations have been found [44], and the functional significance of disease-causing variants are largely unknown. Most NEB-NM patients have a compound heterozygous genotype and, if one of the two variants is missense, then the other is a more disruptive variant such as a nonsense variant or a deletion/insertion [44]. Interestingly, the same variant has been identified in patients with diverse clinical severities, or even with different myopathies [44]. As such, an appropriate model organism is required to better understand the complex pathogenetic mechanisms that underlie the diverse forms of NM. Such a model would also enable potential therapies to be tested in a system that recapitulates the human disease.

A number of murine models have been published [8, $25,46,47,61,89,90]$, and have each provided new knowledge about nebulin function and the potential pathogenesis of NM. However, none of these models possess a compound heterozygous genotype that would be representative of most human NEB-NM cases. Furthermore, there are currently no $\mathrm{Neb}$ models that recapitulate the most common phenotype of NEB-NM. Therefore, we have produced a murine model with compound heterozygous $\mathrm{Neb}$ variants; a missense variant (p.Tyr2303His) in the perfectly conserved tyrosine residue in an actin-binding site, and a nonsense variant (p.Tyr935\%) introducing a premature stop codon in the beginning of the super-repeat region. Our aims were to characterise this new murine model, and to investigate how accurately it recapitulates the phenotype of most patients with NEB-NM.

\section{Materials \& methods C57BL/6J-Neb ${ }^{\mathrm{Y} 2303 \mathrm{H}, \mathrm{Y935X}}$ mice}

Mouse lines with a C57BL/6J background carrying either the $\mathrm{Neb}^{\mathrm{Y} 2303 \mathrm{H}}$ or the $\mathrm{Neb}^{\mathrm{Y} 935 \mathrm{X}}$ variant were selected from a missense mutation library derived from N-ethyl-N-nitrosourea (ENU) mutagenesis (Australian Phenomics Facility, Australian National University, Canberra [5]) on the basis of their potential pathogenicity. The missense variant $\mathrm{NP}_{-}$ 035019.1:p.(Tyr2303His), c.6907 T > C (NM_010889.1), changed the perfectly conserved amino acid tyrosine $(\mathrm{Y}$, $\mathrm{Tyr}$ ) in the last actin-binding site (SDxxYK) of the eighth super repeat (S8). The nonsense variant NP_035019.1: p. $($ Tyr935*), c. $2805 \mathrm{C}>\mathrm{G}$, introduced a premature stop codon in the third super repeat (S3), which was expected to lead to nonsense-mediated RNA decay. To maintain the parental lines, mice heterozygous for each variant, either $\mathrm{C} 57 \mathrm{BL} / 6 \mathrm{~J}-\mathrm{Neb}^{\mathrm{Y} 2303 \mathrm{H}(+/-)}$ or $\mathrm{C} 57 \mathrm{BL} / 6 \mathrm{~J}-\mathrm{Neb}^{\mathrm{Y} 935 \mathrm{X}(+/-)}$, were bred with heterozygous mice of the same genotype, giving rise to homozygous, heterozygous and wild-type genotypes. Resulting mice that were heterozygous for each variant were bred together to generate compound heterozygous mice C57BL/6J-Neb $b^{\mathrm{Y} 2303 \mathrm{H}(+/-), \mathrm{Y} 935 \mathrm{X}(+/-)}$, hereafter annotated $\mathrm{Neb}^{\mathrm{Y} 2303 \mathrm{H}, \mathrm{Y935X}}$. This breeding regime was chosen as homozygous mice for the missense mutation $\left(\mathrm{Neb}^{\mathrm{Y} 2303 \mathrm{H}(+/+)}\right)$ were less fertile than those that were heterozygous $\left(\mathrm{Neb}^{\mathrm{Y} 2303 \mathrm{H}(+/-)}\right)$, and mice homozygous for the nonsense variant $\left(\mathrm{Neb}^{\mathrm{Y} 935 \mathrm{X}(+/+)}\right)$ were not viable. $\mathrm{Neb}^{\mathrm{Y} 2303 \mathrm{H}, \mathrm{Y} 935 \mathrm{X}}$ mice were compared against wild-type littermates or age- and sex-matched C57BL/6J mice.

Mice were housed in a pathogen-free facility at the Animal Resources Centre (Murdoch, Western Australia) and were cared for according to guidelines set by the National Health and Medical Research Council of Australia. Rooms were on a 15:9 h light/dark cycle and mice had ad libitum access to tap water and a regular diet (Specialty Feeds, Western Australia).

Experimentation was approved by the Animal Ethics Committees of the Animal Resources Centre and The University of Western Australia. 


\section{In vivo phenotypic tests}

The compound heterozygous $N e b^{\mathrm{Y} 2303 \mathrm{H}, \mathrm{Y} 935 \mathrm{X}}$ mice, and the heterozygous $\mathrm{Neb}^{\mathrm{Y2} 303 \mathrm{H}(+/-)}$ and $\mathrm{Neb}^{\mathrm{Y} 935 \mathrm{X}(+/-)}$ mice were analysed against wild-type littermate controls of the same age and sex. Bodyweight was measured at 3 and 6 months.

\section{Voluntary exercise}

Mice were housed individually with access to voluntary low-profile wireless running wheels (ENV-044, Med Associates Inc., Fairfax, VT, USA) for 6 consecutive days at 3 and 6 months of age. A wireless USB Interface Hub (DIG-804, Med Associates) was used to collect wheel data that were viewed and extracted using Wheel Manager (SOF-860, Med Associates). Four parameters were calculated for daily performance, including: daily distance travelled, time spent running, average speed and maximum speed. Only data from days 4 to 6 were used for analysis to allow for initial acclimatisation to the wheel.

\section{Grip strength}

At 3 and 6 months of age, each mouse was lifted by its tail until its front paws were in line with the bar of the grip strength meter (Bioseb, Vitrolles, France). Mice were then allowed to reach out to the bar before being gently pulled away at a slow, constant speed. This allowed mice to build up resistance until the grasp was finally broken, at which point the grip strength value $(\mathrm{N})$ was recorded. The test was repeated three times for each mouse. Measurements were discarded if the mouse used only one paw, also used its hind paws, turned backwards during the pull, or left the bar without resistance.

\section{Rotarod}

The day before testing (or as close as possible), mice were acclimatised to the rotarod (Ugo Basile 47,600, Schwenksville, PA, USA) by training for 2 min with slow rod rotation $(4 \mathrm{rpm})$. Mice that fell off during this period were replaced onto the rod until the full time had elapsed. To test performance, mice were placed on the rotarod set at $4 \mathrm{rpm}$ with speed of rotation gradually increased to a maximum of $60 \mathrm{rpm}$ over a period of $3 \mathrm{~min}$. The latency (time to fall) and the speed at this point were recorded. Mice that fell off within the first $10 \mathrm{~s}$ were re-tested after a rest of at least $10 \mathrm{~min}$. However, mice did not get re-tested if they performed a passive rotation (the mouse held on and spun around the rod). When mice did not fall off the rotarod after $5 \mathrm{~min}$, the experiment was ceased. The test was repeated three times within the same session, with each mouse given at least $5 \mathrm{~min}$ to rest between each test.

\section{Transcript level}

$\mathrm{Neb}$ transcript expression in 9-12 month-old gastrocnemius samples from female $\mathrm{Neb}^{\mathrm{Y} 2303 \mathrm{H}, \mathrm{Y} 935 \mathrm{X}}$ mice was compared with expression in the parental lines $\left(\mathrm{Neb}^{\mathrm{Y} 2303 \mathrm{H}(+/+)}, \mathrm{Neb}^{\mathrm{Y} 2303 \mathrm{H}(+/-)}\right.$ and $\left.\mathrm{Ne} b^{\mathrm{Y935X(+/-)}}\right)$ and the C57BL/6J background strain. Skeletal muscle samples from $\mathrm{Neb}^{\mathrm{Y} 935 \mathrm{X}(+++)}$ mice were not included due to their embryonic or early neonatal death, and also as the focus of this study was characterising the compound heterozygous Neb mutant mice.

\section{RNA extraction and CDNA synthesis}

Snap frozen gastrocnemius muscles were divided longitudinally, and half $(\sim 20-30 \mathrm{mg})$ was homogenised in $300 \mu \mathrm{l}$ Buffer RLT with $\beta$-mercaptoethanol using a BioSpec minibead beater (maximum oscillations per min at $30 \mathrm{~s}$ intervals). RNA was subsequently extracted using an RNeasy fibrous tissue mini kit with on-column DNase I treatment (QIAGEN, USA). RNA yield was determined using a Nanodrop ND-1000 spectrophotometer and quality assessed on a $1 \%$ agarose gel. Up to $1 \mu \mathrm{g}$ of RNA was used for cDNA synthesis using the SuperScript III first-strand synthesis system with random hexamer primers (Thermo Fisher, USA). Samples were diluted tenfold for $1 \mu \mathrm{g}$ of starting RNA and scaled accordingly for lower input quantities.

\section{Quantitative RT-PCR}

Transcript abundance of target genes was determined by quantitative reverse-transcriptase PCR (qRT-PCR) using the Rotor-Gene SYBR Green PCR kit (QIAGEN, USA) and a Rotor-Gene Q cycler (QIAGEN, USA). Reactions were performed in $10 \mu \mathrm{l}$ volumes with $0.8 \mu \mathrm{M}$ primers and $1 \mu$ liluted cDNA.

The relative abundance of mutant (p.Tyr2303His, c.6907 $\mathrm{T}>\mathrm{C}, \mathrm{C}$ allele) and wild-type ( $\mathrm{T}$ allele) $\mathrm{Neb}$ transcripts was determined using allele-specific qRT-PCR. Forward primers were specific for either the wild-type (5'- GGACATTGCT AGTGACTTTAAAT) or Tyr2303His mutant allele (5'GGACATTGCTAGTGACTTTAAAC) and used in combination with a non-distinguishing reverse primer (5'CACAGGGCTGGTGTATTTGG). The wild-type allelespecific forward primer also detected transcripts from the mutant p.Tyr $935^{*}$ allele. Standards for assessment of qPCR efficiency were generated by serial dilution of cDNA of the respective genotypes. Cycling conditions were as follows: $95^{\circ} \mathrm{C}$ for $5 \mathrm{~min}, 45$ cycles of $95^{\circ} \mathrm{C}$ for $10 \mathrm{~s}$ and $62^{\circ} \mathrm{C}$ for 15 $\mathrm{s}$, followed by melt curve analysis.

Relative abundance was calculated using the $\Delta \mathrm{Ct}$ method with $\operatorname{Tbp}$ (F: 5' -ATCTACCGTGAATCTTGGCTGT, R: 5' TGTTCTTCACTCTTGGCTCCTG) and Eef2 (F: 5'AGAAAGCCAACATCCGGAACA, R: 5'-GATGGC GGTGGATTTGATTGT) for normalisation. Cycling conditions were as follows: $95^{\circ} \mathrm{C}$ for $5 \mathrm{~min}, 45$ cycles of $95^{\circ} \mathrm{C}$ for $10 \mathrm{~s}$ and $60^{\circ} \mathrm{C}$ for $15 \mathrm{~s}$, followed by melt curve analysis. 


\section{Protein electrophoresis}

Nebulin protein content was analysed using the 1\% SDS agarose gel method [66]. Quadriceps muscle tissue from three female mice per genotype was ground to a fine powder using Dounce homogenisers cooled in liquid nitrogen and acclimated to $-20^{\circ} \mathrm{C}$ for $30 \mathrm{~min}$. Tissue powder was resuspended in a 1:1 mixture of an $8 \mathrm{M}$ urea buffer (in M; 8 urea, 2 thiourea, 0.05 Tris- $\mathrm{HCl}, 0.075$ dithiothreitol, as well as 3\% SDS and $0.03 \%$ bromophenol blue, $\mathrm{pH} 6.8$ ) and $50 \%$ glycerol containing protease inhibitors (in $\mathrm{mM} ; 0.04 \mathrm{E}-64,0.16$ leupeptin, and 0.2 PMSF). Tissue powder was homogenised in solution for $4 \mathrm{~min}$, followed by a $10 \mathrm{~min}$ incubation at $60^{\circ} \mathrm{C}$. Samples were centrifuged at $12,000 \mathrm{rpm}$ and the supernatant was divided into smaller aliquots and flash frozen for storage at $-80{ }^{\circ} \mathrm{C}$. SDS-agarose (SDS-AGE) $1 \%$ gels, run in a Hoefer SE600X vertical gel system (Hoefer Inc.; Holliston, USA), were used to electrophoretically separate nebulin from other proteins, such as titin and myosin heavy chain. The samples were run in five incremental loading volumes. Gels were run at $15 \mathrm{~mA}$ per gel for $3 \mathrm{~h}$ and $15 \mathrm{~min}$, then stained using Neuhoff's Coomassie staining protocol and scanned using a commercial scanner (Epson 800, Epson Corporation, Long Beach CA). Nebulin expression was quantified from the gel images and normalised against myosin heavy chain abundance in each lane.

\section{Histology and immunostaining}

Extensor digitorum longus (EDL), soleus (SOL), tibialis anterior, gastrocnemius, quadriceps femoris, diaphragm, and masseter skeletal muscles were selected on the basis of their suitability for the studies and potential involvement in NEB-NM. The muscles were collected from mice aged 4 to 12 months and snap frozen in isopentane cooled with liquid nitrogen. Sections of $8-10 \mu \mathrm{m}$ were cut on a Leica CM3050S cryostat, then stained with haematoxylin and eosin (H\&E), Gomori trichrome or succinate dehydrogenase (SDH) using standard histochemical techniques [20].

Muscle sections of $10 \mu \mathrm{m}$ were fixed in $2 \%$ paraformaldehyde (PFA), blocked in phosphate buffered saline (PBS) with $10 \%$ foetal calf serum (FCS; Gibco), 1\% bovine serum albumin (BSA; Sigma) and $1 \%$ saponin (Sigma) for $1 \mathrm{~h}$. Mouse monoclonal antibody SERCA1 ATPase (diluted 1:1000, MA3-911, ThermoFisher) was conjugated to Zenon ${ }^{\circ}$ Alexa Fluor 594 (Life Technologies) and incubated with phalloidin-fluorescein isothiocyanate (diluted 1:1000; P5282, Sigma), at $4{ }^{\circ} \mathrm{C}$ overnight. Phalloidin tetramethylrhodamine was used alone (diluted 1:100, P1951, Sigma). Slides were washed in PBS, counterstained in Hoechst (Sigma) and mounted in Fluoromount (Sigma). Muscle sections to be incubated with mouse monoclonal alpha-actinin (diluted 1:
10, EA-53, Sigma) followed the same protocol as above, however, sections were not fixed and saponin was omitted from the blocking solution.

\section{Immunostaining for fibre typing}

Muscle sections of 9-month-old $\mathrm{Neb}^{\mathrm{Y} 2303 \mathrm{H}, \mathrm{Y9} 35 \mathrm{X}}$ and age matched wild-type littermates were labelled as described previously [54]. Briefly, after blocking, mouse $\operatorname{IgG}_{1}$ antibodies against myosin heavy chain MHCI (slow myosin I; diluted 1:20, NCL-MHCs, Leica Biosystems) or MHCIIA (fast myosin IIA; diluted 1:5, SC-71, DSHB) were conjugated to Zenon ${ }^{\circ}$ Alexa Fluor ${ }^{\circ} 594$ (Life Technologies). Primary mouse IgM antibody MHCIIB (fast myosin IIB; diluted 1:10, BF-F3, DSHB) was then added and incubated at $4{ }^{\circ} \mathrm{C}$ overnight. The secondary antibody Zenon $^{\circ}$ Alexa Fluor ${ }^{\circ} 488$ anti-mouse IgM was sequentially incubated at room temperature for $60 \mathrm{~min}$. Slides were washed in PBS, counterstained in Hoescht (Sigma) and mounted in Fluoromount (Sigma).

\section{Myofibre sizes and fibre type proportions}

Fibre typing of the soleus and extensor digitorum longus muscles was conducted on merged images showing (1) MHCI with MHCIIA, and (2) MHCIIA with MHCIIB (see immunostaining for methods). Fibres of each different type were counted and the Feret's diameter measured using ImageJ software (various versions; US National Institute of Health, USA).

\section{Electron microscopy}

Extensor digitorum longus, soleus, tibialis anterior, gastrocnemius, quadriceps femoris and masseter skeletal muscles from 4 to 9-month-old $\mathrm{Neb}^{\mathrm{Y} 2303 \mathrm{H}, \mathrm{Y9} 35 \mathrm{X}}$ and age matched wild-type littermates were prepared for electron microscopy to assess their ultrastructure. After excision, the muscle was immersed in $2.5 \%$ phosphate buffered glutaraldehyde. Tissue was cut into approximately $2 \times 1$ mm strips and processed using a Leica tissue processor, immersed in $1 \%$ aqueous osmium tetroxide, graduated ethanols, propylene oxide, followed by araldite resin. Blocks were polymerised in a $70^{\circ} \mathrm{C}$ oven overnight.

Thin sections were cut on an ultratome (RMC Boeckeler) and stained after drying on copper grids with saturated aqueous uranyl acetate and lead citrate according to standard techniques. The images were captured using a GATAN Orius 11 megapixel digital camera attached to a JEOL 1400 transmission electron microscope.

\section{Whole muscle physiology}

Seven-month-old ( \pm 6 days) male mice were anaesthetised (pentobarbitone via intraperitoneal injection, $40 \mathrm{mg} / \mathrm{kg}$ body weight) and the extensor digitorum longus (EDL) and soleus (SOL) surgically excised 
and mounted onto an in vitro muscle test system (model 1205A; Aurora Scientific Inc.). Muscles were maintained in an organ bath filled with Krebs mammalian ringer solution $(121 \mathrm{mM} \mathrm{NaCl}, 5.4 \mathrm{mM} \mathrm{KCl}$, $1.2 \mathrm{mM} \quad \mathrm{MgSO}_{4} .7 \mathrm{H}_{2} \mathrm{O}, \quad 25 \mathrm{mM} \quad \mathrm{NaHCO}_{3}, \quad 5 \mathrm{mM}$ HEPES, $11.5 \mathrm{mM}$ glucose and $2.5 \mathrm{mM} \mathrm{CaCl}_{2}, \mathrm{pH} 7.3$ ), bubbled with carbogen $\left(5 \% \mathrm{CO}_{2}\right.$ in $\left.\mathrm{O}_{2}\right)$ and maintained at $25^{\circ} \mathrm{C}$ [7].

Isolated muscles were manually adjusted to the optimal muscle length $\left(\mathrm{L}_{\mathrm{o}}\right)$, which was determined as the muscle length that produced maximum twitch force. The twitch time-course was quantitated by measuring contraction time (time-to-peak), maximum rate of force development $(\max \mathrm{dF} / \mathrm{dt})$ and half-relaxation time. The force-stimulation frequency relationship was established by exposing muscles to stimulation frequencies of 10 , 20, 30, 40, 60, 70, 80, 100, 120, 150 and $200 \mathrm{~Hz}$ (EDL), or $5,10,15,20,30,40,60,80,100$ and $120 \mathrm{~Hz}$ (SOL). Muscles were given a $2 \mathrm{~min}$ rest period beween stimulations to prevent fatigue affecting force output. The susceptibility of muscles to eccentric damage was determined by exposing muscles to five sequential eccentric contractions, where muscles were stimulated maximally (EDL, $120 \mathrm{~Hz}$; SOL, $80 \mathrm{~Hz}$ ) for $1 \mathrm{~s}$ while being stretched to $105,110,120,130$ and $140 \%$ of optimal myofibre length at a constant velocity of $1 \mathrm{~L}_{\mathrm{o}} \mathrm{s}^{-1}$. In each eccentric contraction, an initial isometric contraction was induced, and when isometric force had plateaued, the muscle was stretched. A brief, transient increase in force peak occurs at the onset of the stretch, and the height of this transient response was measured (peak stretch-induced force minus isometric plateau force) to provide information about the stiffness of the muscle, with stiffer muscle preparations producing higher transient force peaks. The amplitude of the transient stretchrelated force response was normalised to the amplitude of the preceeding isometric phase of the contraction (\% of isometric plateau force amplitude) [68]. In order to determine the force deficit occurring due to eccentric contraction-induced damage, a maximal isometric contraction was performed before and after each eccentric contraction and the amplitude of these maximal contractions was compared [41].

At the end of the experiment, muscles were removed from the organ bath, stripped of tendons, blotted and weighed. Muscle cross-sectional area (CSA) was determined by dividing muscle wet mass ( $\mathrm{mg}$ ) by the product of the optimal myofibre length and mammalian skeletal muscle density $\left(1.056 \mathrm{mg} / \mathrm{mm}^{3}\right)$ [51]. Optimal myofibre length was calculated by multiplying $\mathrm{L}_{o}$ by a predetermined myofibre to muscle length ratio for the EDL (0.44) and SOL (0.71) [11]. The specific force (force normalised to muscle cross-sectional area, $\mathrm{N} / \mathrm{cm}^{2}$ ) was calculated by dividing isometric force by the CSA.

\section{Single myofibre physiology Myofibre permeabilisation}

Relaxing and activating solutions contained $4 \mathrm{mMMg}$ ATP, $1 \mathrm{mM}$ free $\mathrm{Mg}^{2+}, 20 \mathrm{mM}$ imidazole, $7 \mathrm{mM}$ EGTA, $14.5 \mathrm{mM}$ creatine phosphate, and $\mathrm{KCl}$ to adjust the ionic strength to $180 \mathrm{mM}$ and $\mathrm{pH}$ to 7.0. The concentrations of free $\mathrm{Ca}^{2+}$ were $10^{-9.00} \mathrm{M}$ (relaxing solution) and $10^{-}$ ${ }^{4.50} \mathrm{M}$ (activating solution).

After excision, the tibialis anterior muscles from 6month-old male mice were placed in relaxing solution at $4{ }^{\circ} \mathrm{C}$. Bundles of $\sim 50$ myofibres were dissected free and tied with surgical silk to glass capillary tubes at slightly stretched lengths. Bundles were treated with skinning solution (relaxing solution with glycerol; $50: 50 \mathrm{v} / \mathrm{v}$ ) for $24 \mathrm{~h}$ at $4{ }^{\circ} \mathrm{C}$, and transferred to $-20^{\circ} \mathrm{C}$. For long-term storage muscle bundles were treated with sucrose, a cryoprotectant, and within 1-2 weeks detached from the capillary tubes, snap frozen in liquid nitrogen-chilled isopentane and stored at $-80^{\circ} \mathrm{C}$ [24].

\section{Single myofibre force mechanics}

On the day of experiment, bundles were de-sucrosed, transferred to a relaxing solution, and single myofibres dissected. Myofibres were individually attached between connectors leading to a force transducer (model 400A; Aurora Scientific) and a lever arm system (model 308B; Aurora Scientific). Sarcomere length was set to $2.50 \mu \mathrm{m}$ and the temperature to $15^{\circ} \mathrm{C}[48,49,60]$. Myofibre CSA was approximated from width and depth measures, assuming an elliptical circumference. Absolute maximal isometric force generation was calculated as the difference between the total tension in the activating solution ( $\mathrm{pCa} 4.50)$ and the resting tension measured for the same myofibre in relaxing solution. Specific force was defined as absolute force divided by CSA.

Apparent rate constants of force redevelopment $\left(k_{\mathrm{tr}}\right)$ were measured using a mechanical slack-restretch manoeuver. Briefly, each myofibre was transferred from relaxing solution to activating solution and allowed to generate steady-state force. The myofibre was then rapidly slackened (within $1-2 \mathrm{~ms}$ ) by $20 \%$ of its original length, resulting in a rapid reduction of force to near zero. This was followed by a brief period of unloaded shortening $(20 \mathrm{~ms})$ before rapidly re-stretching to its original length [10]. $k_{\mathrm{tr}}$ was approximated by linear transformation of the half-time of force redevelopment $\left(k_{\mathrm{tr}}=\right.$ $\left.0.693 / \mathrm{t}_{1 / 2}\right)$ as described previously [70].

Maximum unloaded shortening velocity $\left(\mathrm{V}_{0}\right)$ was also calculated by the slack test. Once steady-state isometric force was reached, nine slacks of various amplitudes were rapidly introduced (within 1-2 ms) at one end of the myofibre [22]. Slacks were applied at different amplitudes ranging from 7 to $13 \%$ of the myofibre length $[58,59]$. The myofibre was re-extended between releases (while relaxed) 
in order to minimize changes to sarcomere length. The time required to take up the imposed release was measured from the onset of the length step to the beginning of the tension redevelopment. A straight line was fitted to a plot of release length versus time, using least-squares regression from at least four data points. $\mathrm{V}_{0}$ for each myofibre segment was calculated by dividing the line slope by the myofibre segment length [22].

\section{Myofilament measurements}

On the day of experimentation, single myofibres were de-sucrosed, and individually dissected. Arrays of approximately nine myofibres were prepared at room temperature (RT) and used to measure thin and thick filament lengths. For each myofibre, both ends were clamped to half-split copper meshes designed for electron microscopy (SPI G100 2010C-XA, width, $3 \mathrm{~mm}$ ) that were glued to cover slips (Menzel-Gläser, $22 \times 50$ $\mathrm{mm}$, thickness $0.13-0.16 \mathrm{~mm}$ ).

Myofibres were fixed in 4\% PFA and permeabilised with $0.1 \%$ Triton X-100 in PBS. Tissues were blocked in $10 \%$ goat serum/PBS before incubation with primary antibodies diluted in goat serum blocking solution. Tropomodulin 4 (Tmod4) was detected using a rabbit IgG anti-TMOD4 antibody (1:100; R3577bl3c [26]) and $\alpha-$ actinin with a mouse $\operatorname{IgG}_{1}$ anti- $\alpha$-actinin antibody (1: 500; Clone EA-53, Abcam). For thin filament length measurements, myofibres were treated with Alexa 594conjugated phalloidin (1:100, Molecular Probes). For detection, tissues were incubated with Alexa 488- or 594-conjugated secondary antibodies/PBS (1:1000; Molecular Probes).

Images were collected using a CellVoyager ${ }^{\mathrm{rt}}$ (CV1000) Confocal Scanner Box microscope using a 60x oil objective lens. The CV100 software was used for image collection and the myofibres were analysed using Distributed Deconvolution (DDecon) [56].

\section{Statistical analyses}

The unpaired Mann-Whitney, unpaired t-test, and Welch's t-test or two-way ANOVA were used for statistical comparison of datasets, with $p$-values $<0.05$ considered to be statistically significant. Fibre typing and whole muscle physiology data are presented as mean \pm SEM, and the rest of the data are presented as mean \pm SD.

\section{Results}

$\mathrm{Neb}^{\mathrm{Y} 2303 \mathrm{H}, \mathrm{Y935X}}$ mice do not have an apparent shorter lifespan than wild-type mice

Compound heterozygous mice $\left(\mathrm{Neb}^{\mathrm{Y} 2303 \mathrm{H}, \mathrm{Y} 935 \mathrm{X}}\right)$ were produced at an occurrence of approximately one in eight offspring, as expected by Mendelian ratios. Limited numbers of $\mathrm{Neb}^{\mathrm{Y} 935 \mathrm{X}(++)}$ mice were born, well below proportions expected by Mendelian ratios, and mice with this genotype all died by 5 days after birth. The lifespan of $\mathrm{Neb}^{\mathrm{Y} 2303 \mathrm{H}}$ and $N e b^{\mathrm{Y} 2303 \mathrm{H}, \mathrm{Y} 935 \mathrm{X}}$ mice was not overtly reduced, as all survived past the oldest time point in this study (12 months), unless sacrificed earlier.

\section{$\mathrm{Neb}^{\mathrm{Y} 2303 \mathrm{H}, \mathrm{Y935X}}$ mice express the p.Tyr2303His Neb allele at $\sim 50 \%$ of normal RNA levels, while the p.Tyr935* transcript is not detected (Fig. 1a-c)}

In order to ascertain the effects of the p.Tyr935* and p.Tyr2303His variants (Fig. 1a) on transcript abundance we performed two sets of qPCR reactions. The first qPCR was designed to detect the presence of the wild-type (WT) allele (but not amplify the p.Tyr2303His allele) and is presented as a percentage of WT levels (with C57BL/6J representing 100\%). Since the primers were designed after the p.Tyr $935^{*}$ stop codon, full length $\mathrm{Neb}$ transcript produced from the p.Tyr $935^{*}$ allele (if any) would also be detected. It was hypothesised that the p.Tyr935* variant would result in nonsense-mediated mRNA decay. Accordingly, heterozygous $\mathrm{Neb}^{\mathrm{Y9} 93 \mathrm{X}(+/-)}$ mice expressed $\mathrm{Neb}$ at $\sim 50 \%$ of WT levels suggesting that the p.Tyr $935^{*}$ allele is indeed degraded (Fig. 1b). Similarly, mice that were heterozygous for the p.Tyr2303His variant $\left(\mathrm{Neb}^{\mathrm{Y} 2303 \mathrm{H}(+/-)}\right)$ expressed WT Neb at $50 \%$ of control WT levels (Fig. 1b). Negligible off-target priming (WT) was detected in $\mathrm{Neb}^{\mathrm{Y} 2303 \mathrm{H}, \mathrm{Y} 935 \mathrm{X}}$ and $\mathrm{Neb}^{\mathrm{Y} 2303 \mathrm{H}(+++)}$ samples (Fig. 1b), which is indicative of the specificity of this reaction as these two genotypes should not express any WT Neb transcript.

The second qPCR was performed with primers designed to detect only the p.Tyr2303His allele and the results are presented as a percentage relative to p.Tyr2303His homozygous samples (e.g. 100\% mutant). In line with the expected consequences of the p.Tyr2303His variant, muscles from compound heterozygous $\mathrm{Neb}^{\mathrm{Y} 2303 \mathrm{H}, \mathrm{Y} 935 \mathrm{X}}$ and heterozygous $\mathrm{Neb}^{\mathrm{Y} 2303 \mathrm{H}(+/-)}$ mice expressed the mutant p.Tyr2303His allele at 50\% of the level observed in muscles from homozygous $\mathrm{Neb}^{\mathrm{Y} 2303 \mathrm{H}(+/+)}$ mice (Fig. 1c). Muscles from $\mathrm{Neb}^{\mathrm{Y} 935 \mathrm{X}(+/-)}$ and C57BL/6J mice produced negligible levels of the p.Tyr2303His allele, as expected, due to absence of this allele in these mice (Fig. 1c). Together these results confirm that $\mathrm{Neb}^{\mathrm{Y} 2303 \mathrm{H}, \mathrm{Y9} 35 \mathrm{X}}$ mice express a reduced total abundance of $\mathrm{Neb}$ transcript, likely due to degradation of the p.Tyr935* transcript, and all Neb transcript produced contains the p.Tyr2303His variant.

\section{Nebulin protein levels remain comparable between the strains (Fig. 1d-e)}

We investigated whether nebulin protein levels were reflective of the nebulin transcript results detected in C57BL/6J, Neb $b^{\mathrm{Y} 2303 \mathrm{H}(+/+)}, \mathrm{Neb}^{\mathrm{Y935X(+/-)}}$ and compound heterozygous $N e b^{\mathrm{Y} 2303 \mathrm{H}, \mathrm{Y} 935 \mathrm{X}}$ mice. Nebulin protein levels remained comparable between all four strains analysed (Fig. 1d-e). 


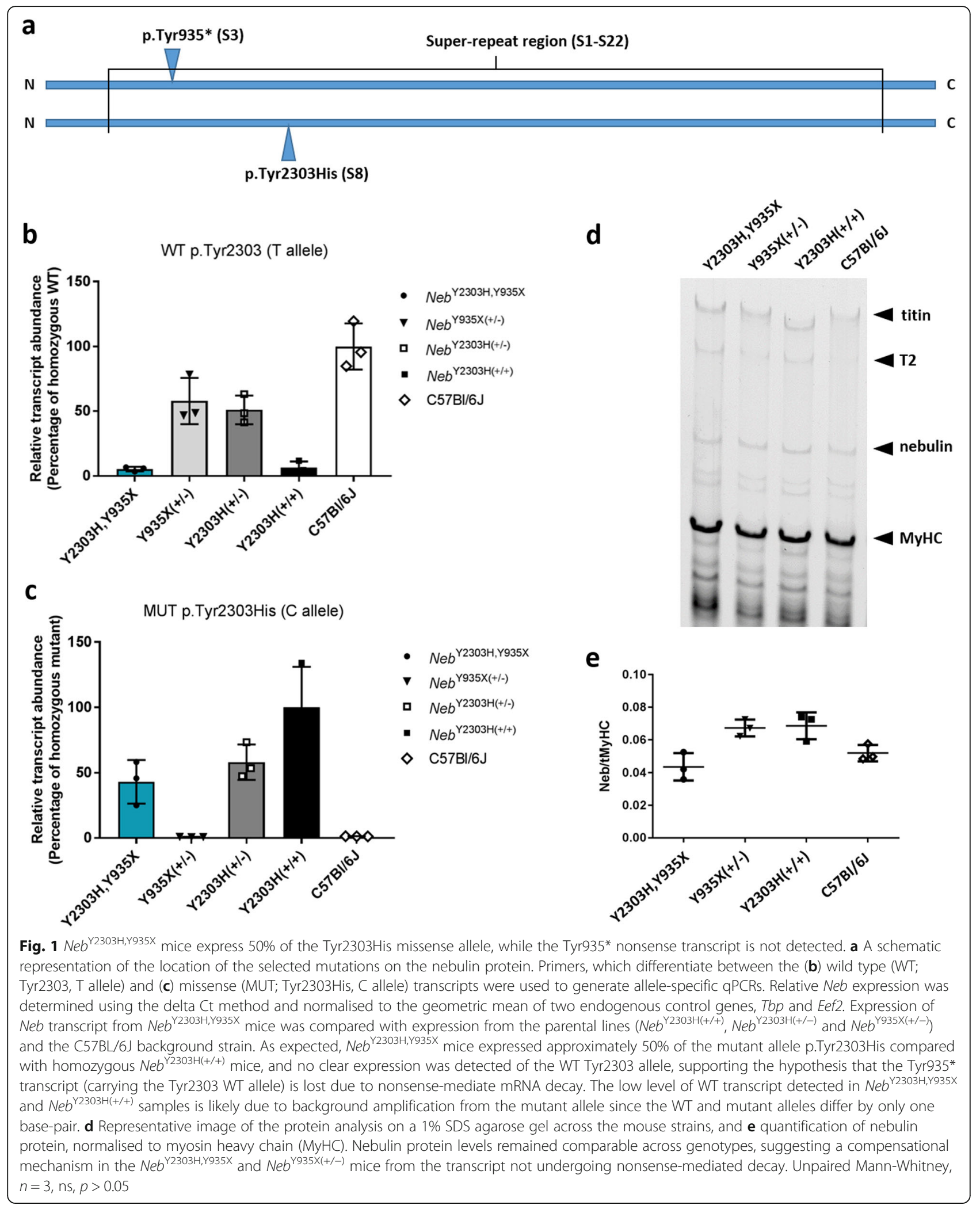


Nemaline bodies, core-like structures, split myofibres, internal nuclei and mitochondrial accumulations are present in some muscles from $\mathrm{Neb}^{\mathrm{Y2303 \textrm {H }}, \mathrm{Y935X}}$ mice (Fig. 2)

In order to determine whether muscles of $\mathrm{Neb}^{\mathrm{Y} 2303 \mathrm{H}, \mathrm{Y} 935 \mathrm{X}}$ mice exhibited similar histological features to patients with NM, a range of skeletal muscles representing different compositions of fast and slow myofibre proportions were studied. Gomori trichrome and H\&E staining revealed large quantities of accumulations resembling nemaline bodies characteristic of NM disease in patients (Fig. 2a and b, white arrowheads). The accumulations were most prominent in the gastrocnemius and quadriceps of $N e b^{\mathrm{Y} 2303 \mathrm{H}, \mathrm{Y} 935 \mathrm{X}}$ mice and were less abundant in the masseter, extensor digitorum longus and diaphragm at all time points studied. Interestingly, no nemaline bodies were found in soleus or tibialis anterior muscles. Phalloidin staining confirmed that the accumulations contained filamentous actin (Fig. 2c, white arrowheads), and these accumulations also stained positive for alphaactinin. SDH staining and fibre typing with $\mathrm{MHC}$ antibodies indicated that the aggregates were predominantly found in MHC type IIB (fast, glycolytic) fibres (Fig. 2d-f).

Tubular aggregates were also apparent in the skeletal muscles of male mice. Although this is a non-specific finding in older inbred male mice, male $N e b^{\mathrm{Y} 2303 \mathrm{H}, \mathrm{Y} 935 \mathrm{X}}$ mice at 9 months of age had abundant and abnormally large tubular aggregates, comparable to those usually seen in male C57BL/6J mice at 18 months of age [3]. Tubular aggregates were distinguished from actincontaining nemaline bodies by SERCA staining, as well as $\mathrm{SDH}$ and phalloidin staining, as tubular aggregates are negative for both of these markers (Fig. 2a-c).

Additional pathological features were also found in different muscles. Of the skeletal muscles studied, core-like structures were evident in the oxidative fibres of the tibialis anterior (Fig. 2g-i) and masseter muscles, and occasionally in the quadriceps (Fig. 2k). Core-like structures did not correspond to areas of nemaline body aggregation, and they stained negative with SDH staining, confirming that these areas were devoid of mitochondria. Cores were only present in a subset of fibres (fast and slow), and could not be confirmed with electron microscopy. Several split myofibres were seen in the quadriceps (Fig. 2j-1) and extensor digitorum longus. Furthermore, internal nuclei and apparent myofibre size variation were observed in the quadriceps, but due to the heterogeneity of the quadriceps muscle, these features were not further quantified (Fig. 2j-l).

Transmission electron microscopy of the gastrocnemius from $N e b^{\mathrm{Y} 2303 \mathrm{H}, \mathrm{Y} 935 \mathrm{X}}$ mice validated the presence of electron-dense material indicative of nemaline bodies (Fig. 3a-f, seen in aggregates and as expansions of Z-disc structures), and tubular aggregates (Fig. 3a). The nemaline bodies were large and irregular, and in some instances clearly originated from the $\mathrm{Z}$ discs (thickened $Z$ discs [20], Fig. 3d-f). Large intermyofibrillar aggregates of mitochondria were seen in a subpopulation of myofibres of all skeletal muscles studied, with variation in mitochondrial size within the aggregates (Fig. 3g-i).

\section{$\mathrm{Neb}^{\mathrm{Y} 2303 \mathrm{H}, \mathrm{Y935X}}$ mice have significantly smaller myofibre diameters (Fig. 4)}

MHC fibre types (I, IIA, IIB, hybrid I/IIA and hybrid IIA/ IIX) from the extensor digitorum longus (EDL) and soleus (SOL) of 9-month-old female $N e b^{\mathrm{Y} 2303 \mathrm{H}, \mathrm{Y} 935 \mathrm{X}}$ mice were counted and fibre diameters measured (for the numerical data, see Additional file 1). All myofibres that contained a fast MHC (type IIA, IIB, IIA and/or IIX) were significantly smaller in the EDL from $N e b^{\mathrm{Y} 2303 \mathrm{H}, \mathrm{Y} 935 \mathrm{X}}$ mice compared with age-matched wild-type littermates. However, myofibres expressing slow MHC (type I) trended towards being hypertrophied in the EDL of $N e b^{\mathrm{Y} 2303 \mathrm{H}, \mathrm{Y} 935 \mathrm{X}}$ mice (Fig. 4a; type I: $+19.2 \%, p=0.0854$, ns; type IIA: $-11.3 \%, p<$ 0.0001 ; type IIB: $-6.6 \%, p<0.0001$; type IIA/IIX: $-8.9 \%$, $p=0.006)$. All myofibres from the SOL of $\mathrm{Neb}^{\mathrm{Y} 2303 \mathrm{H}, \mathrm{Y} 935 \mathrm{X}}$ mice were significantly smaller (Fig. $4 \mathrm{~b}$; type I: $-8.4 \%, p<$ 0.0001 ; type IIA: $-10.6 \%, p<0.0001$, type IIB: $-27.6 \%$, $p=0.0015$; type IIA/IIX: $-21.7 \%, p<0.0001)$.

Fibre-type proportions (as \% of all myofibres) in the EDL (Fig. 4c; $n=3$ ) and SOL (Fig. $4 \mathrm{~d} ; n=3$ ) from $N e b^{\mathrm{Y} 2303 \mathrm{H}, \mathrm{Y} 935 \mathrm{X}}$ mice were trending towards being significantly different when compared with wild-type littermate controls. In both muscles the oxidative fibre types (slow MHC I or fast IIA) were more abundant (EDL, type I: $+4.68 \%, p=0.4$, ns; type IIA $+16.17 \%, p=0.1$, ns; SOL, type I: $+13.37 \%, p=0.1$, ns), whereas there were less fast twitch, glycolytic type IIB fibres (EDL, type IIB: $-27.74 \%, p=0.1$, ns; SOL, type IIB: $-4.92 \%, p=0.1$, ns). A predominance of slow, type I fibres is common in $N E B-\mathrm{NM}$ patients [86] so it is promising that our mouse model is displaying a similar trend.

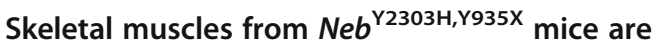 susceptible to eccentric contraction-induced damage (Fig. 5)}

Analysis of whole muscle physiology in vitro showed twitch contraction times were faster (reduced time-to-peak values) in the extensor digitorum longus (EDL) muscles from $N e b^{\mathrm{Y} 2303 \mathrm{H}, \mathrm{Y} 935 \mathrm{X}}$ mice compared with age-matched wildtype littermate controls $(p=0.0234)$. No difference in soleus (SOL) twitch contraction times was found between groups $(p=0.0592$, ns). All other twitch parameters and maximum specific force were similar in muscles from $\mathrm{Neb}^{\mathrm{Y} 2303 \mathrm{H}, \mathrm{Y9} 35 \mathrm{X}}$ and control mice (Additional file 2). However, significant decreases in normalised force were found in $N e b^{\mathrm{Y} 2303 \mathrm{H}, \mathrm{Y} 935 \mathrm{X}}$ muscles compared with wildtype controls at low stimulation frequencies: EDL at $20 \mathrm{~Hz}$ $(p=0.0385)$ and $30 \mathrm{~Hz}(p=0.0002)$; SOL from $10 \mathrm{~Hz}-30$ 

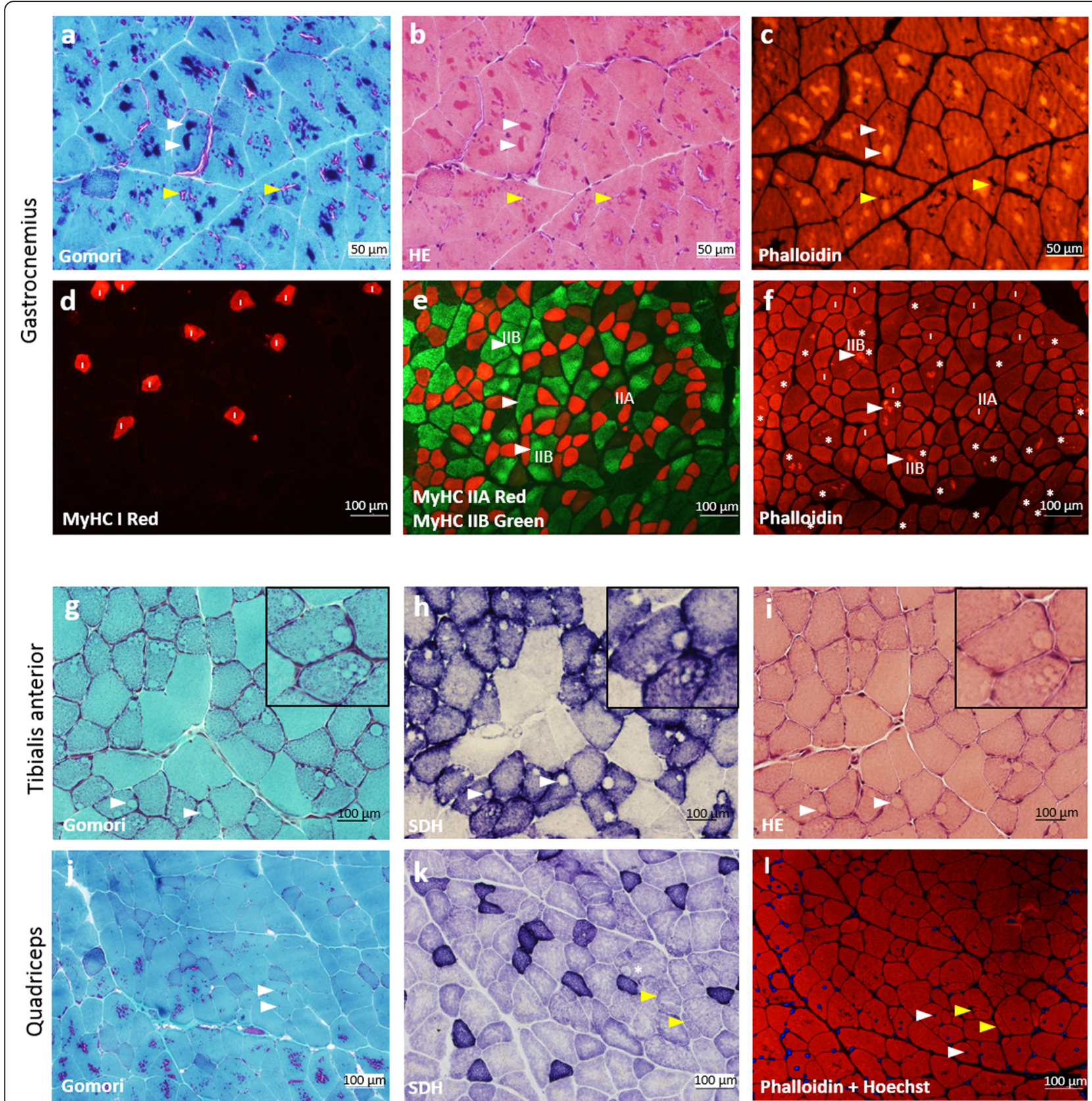

Fig. 2 Histology and immunostaining of different skeletal muscles from Neb ${ }^{\Upsilon 2303 \mathrm{H}, Y 935 \mathrm{X}}$ mice demonstrate multiple pathological features. a-c Nemaline bodies (white arrowheads; purple staining in Gomori, and intense staining with TRITC-phalloidin) in serial cross-sections of gastrocnemius (9-month-old male) stained with Gomori trichrome (a), H\&E (b) and TRITC-phalloidin (c). Tubular aggregates (yellow arrowheads; pink in Gomori, negative with phalloidin) are a non-specific finding in older male mice from certain inbred strains. $\mathbf{d}$-e Fibre typing was performed on serial sections using MyHC I (d), and MyHC IIA and IIB (e), antibodies. f TRITC-phalloidin visualised the actin-containing nemaline bodies most commonly locating in the fast MyHC type IIB fibres. All myofibres containing definite nemaline bodies are indicated with an asterisk $\left.{ }^{*}\right)$, and 25/25 of these fibres are MyHC type IIB. Nemaline bodies were occasionally found in MyHC IIA fibres, however, no nemaline bodies were found in MyHC type I (slow) fibres (all type I fibres are indicated with an "l"). $\mathbf{g - i}$ Cross-sections of tibialis anterior (12-month-old female) stained with Gomori trichrome (g), SDH (h), and H\&E (i), showing core-like structures in several myofibres (white arrowheads and inset). $\mathbf{j}-\mathbf{I}$ Cross-sections of quadriceps (9 month male) stained with Gomori trichrome (j), SDH (k), and TRITC-phalloidin with Hoechst (I) showing internal nuclei (white arrowheads), split fibres (yellow arrowheads) and an occasional core-like structure $\left(^{*}\right)$ 

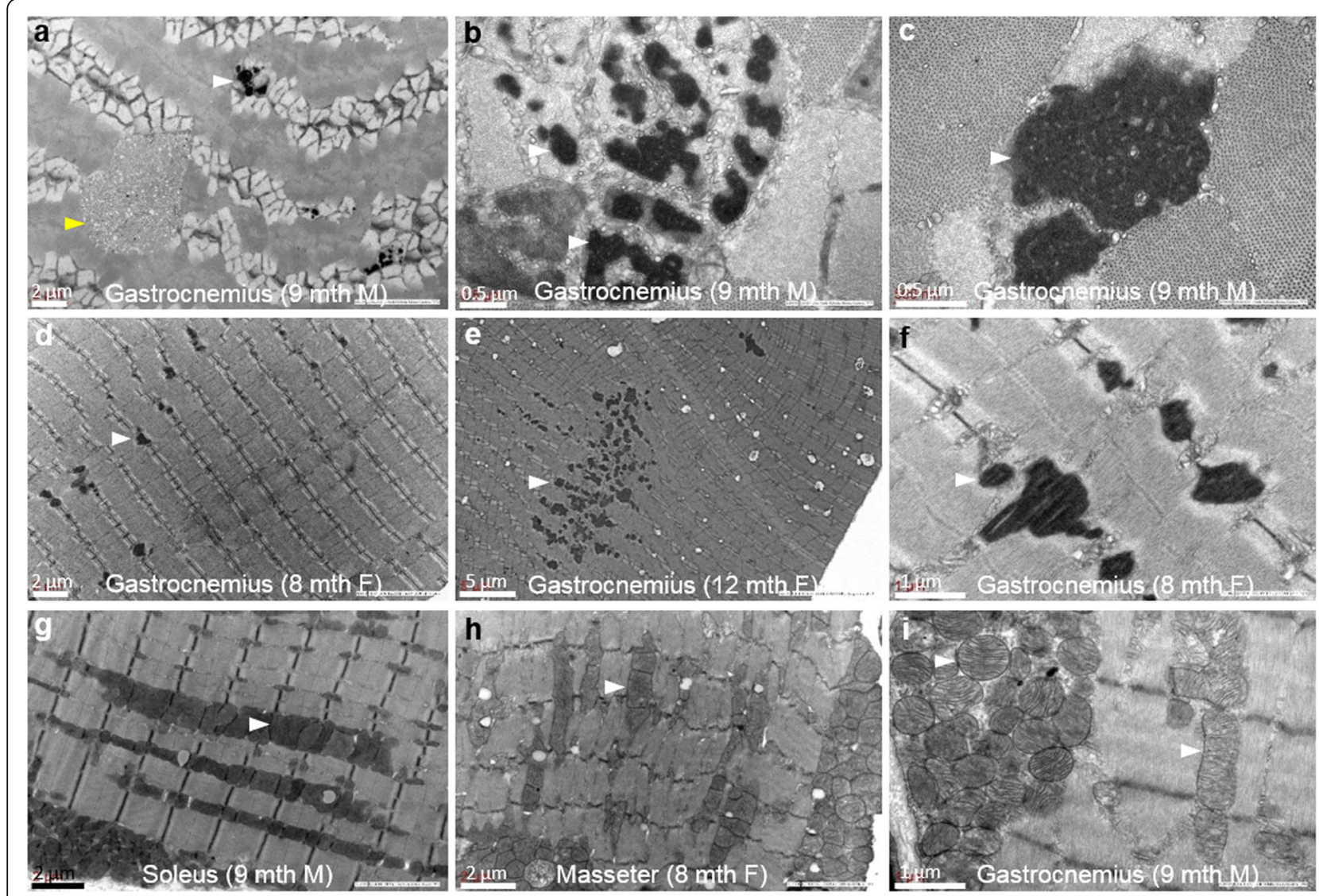

Fig. 3 Ultrastructural analysis of muscles from Neb ${ }^{\mathrm{Y} 2303 \mathrm{H}, \mathrm{Y} 935 \mathrm{X}}$ mice confirmed nemaline bodies, tubular aggregates and pleomorphic

mitochondria. a-c Electron microscopic images showing nemaline bodies (white arrowheads) and tubular aggregates (yellow arrowheads) from a 9-month-old male mouse. $\mathbf{d}$-f Nemaline bodies originating from the $\mathbf{Z}$ disc identified in 8-12-month-old female mice. $\mathbf{g}$-i Large intermyofibrillar aggregates of mitochondria were seen in all the muscles studied, with notable variation in mitochondrial size within the aggregates

$\mathrm{Hz}(p<0.0001), 40 \mathrm{~Hz}(p=0.0018)$ and $50 \mathrm{~Hz}(p=0.0307)$ (Fig. $5 \mathrm{a}, \mathrm{b})$. The EDL from $\mathrm{Neb}^{\mathrm{Y} 2303 \mathrm{H}, \mathrm{Y} 935 \mathrm{X}}$ mice was more susceptible to eccentric contraction-induced muscle damage than wild-type controls when stretched from 120 to $140 \%$ of $\mathrm{L}_{\mathrm{o}}$ (optimal muscle length) during eccentric activation (Fig. 5c, d). According to the transient stretch-related

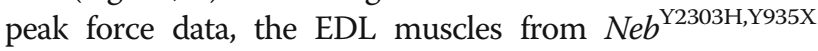
mice were significantly stiffer than those from wild-type controls $\left(\mathrm{Neb}^{\mathrm{Y} 2303 \mathrm{H}, \mathrm{Y9} 95 \mathrm{X}}\right.$ EDL transient stretch response was $20 \%$ greater than the wild-type response during $140 \%$ of $\mathrm{L}_{\mathrm{o}}$ stretch, $\left.p=0.0008\right)$. In contrast, the SOL from $\mathrm{Neb}{ }^{\mathrm{Y} 2303 \mathrm{H}, \mathrm{Y} 935 \mathrm{X}}$ mice exhibited a significant decrease (15\%) in stiffness during $140 \%$ of $L_{o}$ stretch compared with the wild-type response $(p=0.0283)$ (Fig. 5e, f).

\section{Altered myosin cross-bridge kinetics potentially underlying force depression in muscles from $\mathrm{Neb}^{\mathrm{Y} 2303 \mathrm{H}, \mathrm{Y935X}}$ mice (Fig. 6a-c)}

The single myofibre preparation allows direct measurements of contractility with an intact myofilament lattice without the confounding effects of nerves, excitation- contraction coupling, myofibre architecture and intercellular connective tissue. Tibials anterior muscles were isolated from 6-month-old male mice and the dissected myofibres (mainly IIX and IIB fibres) were used in the experiments. The mean maximum specific force was $22 \%$ lower in $\mathrm{Neb}^{\mathrm{Y} 2303 \mathrm{H}, \mathrm{Y} 935 \mathrm{X}}$ mice than in wild-type mice (Fig. 6a, $p=0.036$ ). Additionally, the mean $k_{\text {tr }}$ (rate of force redevelopment) was $28 \%$ slower in $\mathrm{Neb}^{\mathrm{Y} 2303 \mathrm{H}, \mathrm{Y} 935 \mathrm{X}}$ mice (Fig. $6 \mathrm{~b} ; p=0.012$ ). The $\mathrm{V}_{0}$ (maximum unloaded shortening velocity) was unaffected in $\mathrm{Neb}^{\mathrm{Y} 2303 \mathrm{H}, \mathrm{Y} 935 \mathrm{X}}$ mice (Fig. 6c). Taken together, these results indicate a potential alteration of myosin cross-bridge kinetics underlying the force depression. $k_{\mathrm{tr}}$ reflects the myosin cross-bridge cycle turnover rate and according to the two-state cross-bridge model, it is proportional to $f_{\text {app }}+g_{\text {app }}$, with $f_{\text {app }}$ being the rate constant for attachment and $g_{\text {app }}$ the rate constant for detachment. $\mathrm{V}_{0}$ has $g_{\text {app }}$ as a rate limiting step. Hence, in $N e b^{\mathrm{Y} 2303 \mathrm{H}, \mathrm{Y} 935 \mathrm{X}}$ mice the combination of decreased $k_{\mathrm{tr}}$ and maintained $\mathrm{V}_{0}$ indicates a dramatic reduction in $f_{\text {app }}$. This is likely to shorten the time spent by each myosin molecule in a strongly bound force-producing 


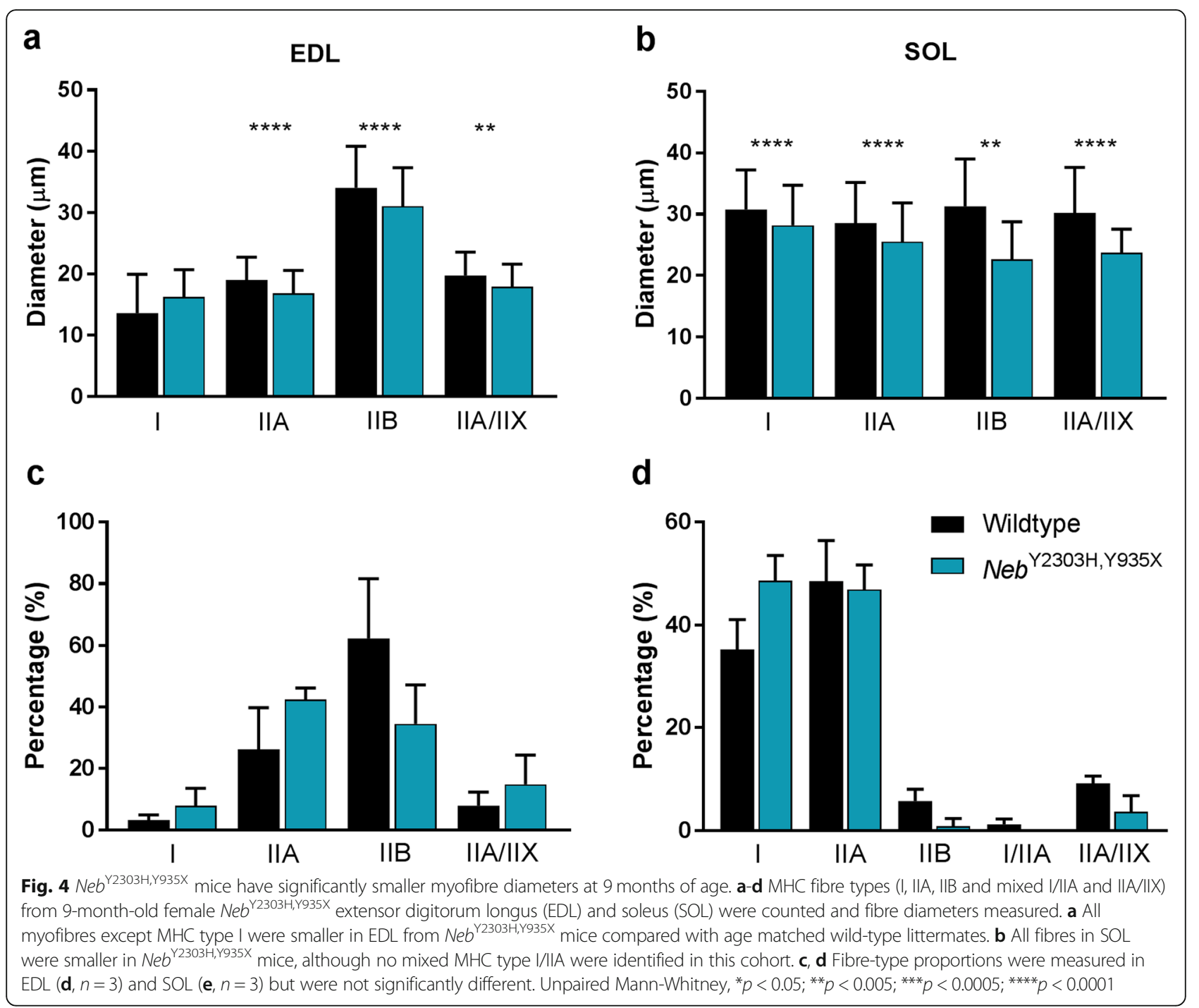

conformation limiting the fraction of active myosin crossbridges. Note that fibres were not assessed for their myosin heavy chain composition. Hence, it is not totally excluded that some of our results may be due to fibre type differences.

Muscles from $\mathrm{Neb}^{\mathrm{Y} 2303 \mathrm{H}, \mathrm{Y935X}}$ mice have a preserved thin filament length (Fig. 6d)

Immunostaining of single myofibres with $\operatorname{Tmod} 4$ and $\alpha$ actinin antibodies were used to measure sarcomeric distances. No differences in thin filament lengths were detected over a range of sarcomere lengths (Fig. 6d) in $N e b^{\mathrm{Y} 2303 \mathrm{H}, \mathrm{Y} 935 \mathrm{X}}$ mice compared with wild-type mice. Alpha-actinin was correctly localised and showed regular striation patterns, indicating preserved Z-disc structures in $N e b^{\mathrm{Y} 2303 \mathrm{H}, \mathrm{Y} 935 \mathrm{X}}$ mice.

\section{Assessment of exercise function revealed that} $\mathrm{Neb}^{\mathrm{Y} 2303 \mathrm{H}, \mathrm{Y935X}}$ mice display a mild phenotype Female $N e b^{\mathrm{Y} 2303 \mathrm{H}, \mathrm{Y} 935 \mathrm{X}}$ mice were significantly smaller than controls at 6 months, and similarly, Neb $b^{\text {Y935X (+/-) }}$ females weighed significantly less at both 3 months and 6 months (Additional file 3a: Six month time point). Body weights of male and female $\mathrm{Neb}^{\mathrm{Y} 2303 \mathrm{H}}$ mice collected at 3 months and 6 months of age were not significantly different to wild-type littermate controls.

Investigation of muscle function using grip strength test only showed a deficit in muscle force in 6 month female $N e b^{\mathrm{Y} 2303 \mathrm{H}, \mathrm{Y} 935 \mathrm{X}}$ mice (Additional file $3 \mathrm{~b}$ ). There was no distinction in force between wild-type controls and male $N e b^{\mathrm{Y} 2303 \mathrm{H}, \mathrm{Y} 935 \mathrm{X}}$ mice as was also the case for $N e b^{\mathrm{Y} 2303 \mathrm{H}}$ or $N e b^{\mathrm{Y} 935 \mathrm{X}}$ mice for either sex or time point analysed.

Investigating muscle function using voluntary running wheels yielded inconclusive results due to high variability 


\section{a}

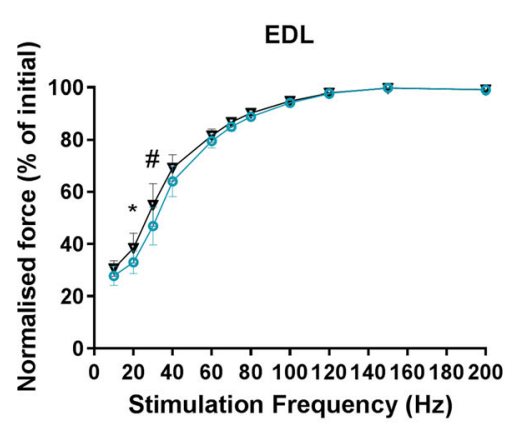

C

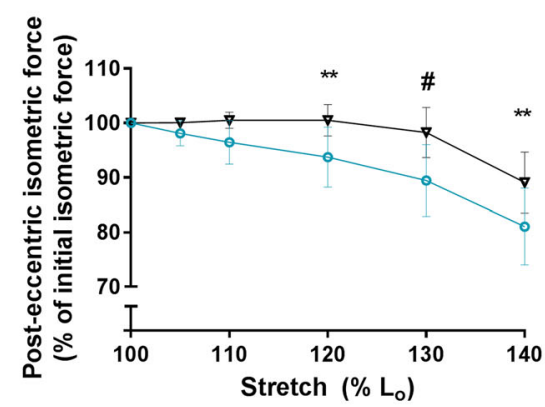

e

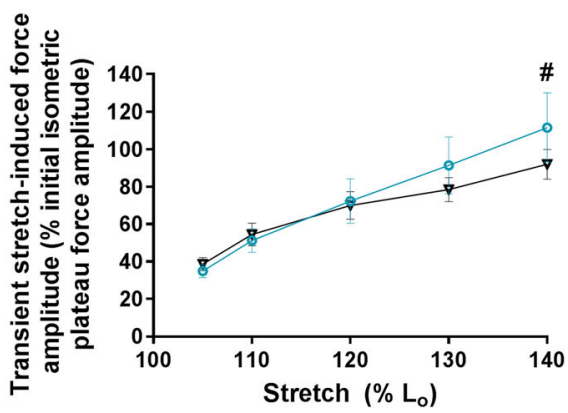

b

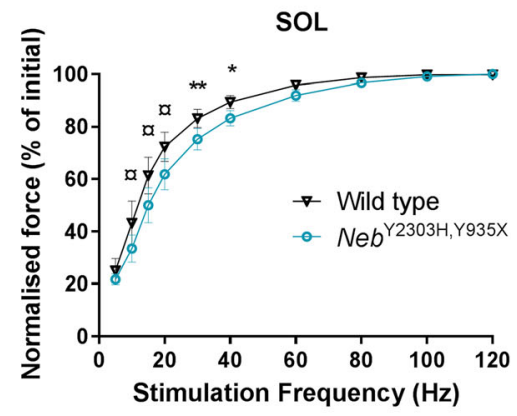

d

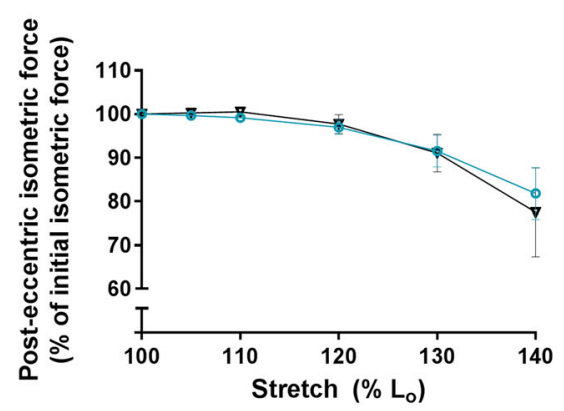

$\mathbf{f}$

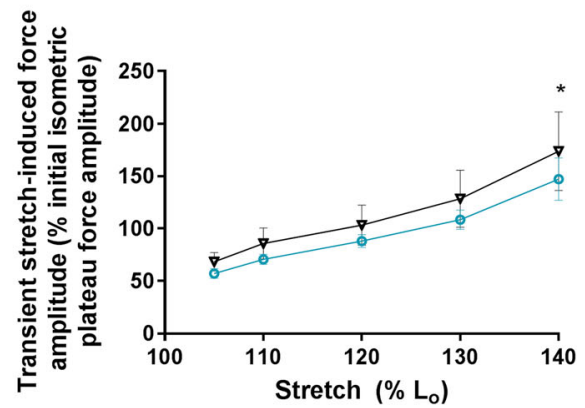

Fig. 5 Whole-muscle physiology experiments showed the $\mathrm{Neb}^{\mathrm{Y} 2303 \mathrm{H}, \mathrm{Y} 935 \mathrm{X}}$

EDL muscle was susceptible to eccentric contraction-induced damage. a, $\mathbf{b}$ Whole-muscle in vitro contractile analysis of extensor digitorum longus (EDL) and soleus (SOL) from male mice at 7 months of age showed a significant deficit in normalised force production in $\mathrm{Neb}^{\mathrm{Y} 2303 \mathrm{H}, \mathrm{Y9} 93 \mathrm{X}}$ at low-stimulation frequencies. $\mathbf{c}, \mathbf{d}$ EDL Neb ${ }^{\mathrm{Y} 2303 \mathrm{H}, \mathrm{Y} 935 \mathrm{X}}$ muscle was more susceptible to damage by eccentric contractions involving stretches to 120 to $140 \%$ of $L_{0}$ than wild type. e, $\mathbf{f}$ Transient stretch-induced force responses were higher in $\mathrm{Neb}^{\mathrm{Y} 2303 \mathrm{H}, \mathrm{Y} 935 \mathrm{X}}$ EDL muscles compared with wild type, suggesting increased stiffness in Neb ${ }^{\mathrm{Y} 2303 \mathrm{H}, \mathrm{Y} 935 \mathrm{X}}$ EDL muscles. In contrast, transient stretch-induced force responses were lower in $\mathrm{Neb}^{\mathrm{Y} 2303 \mathrm{H}, \mathrm{Y} 935 \mathrm{X}} \mathrm{SOL}$ muscles compared with wild type, suggesting greater compliance in Neb ${ }^{\mathrm{Y} 2303 \mathrm{H}, \mathrm{Y} 935 \mathrm{X}}$ SOL muscles. $n=7$, Two-way ANOVA, ${ }^{*} p<0.05 ;{ }^{* *} p<0.005 ; \# p<0.0005 ;$; $p<0.0001$

in each cohort analysed. While female $\mathrm{Neb}^{\mathrm{Y} 2303 \mathrm{H}, \mathrm{Y9} 35 \mathrm{X}}$ mice displayed a significantly decreased performance in daily distance, average speed and maximum speed at 6 months (Additional file 3c) these results were not observed at the 3 month time point, or in male mice at either time point. Similarly, no significant differences were seen in any parameter for male and female $\mathrm{Neb}^{\mathrm{Y} 2303 \mathrm{H}}$ or $N e b^{\mathrm{Y} 935 \mathrm{X}}$ mice at either time point. Some mice were capable of running distances comparable to wild-type littermate controls while others did not run at all. Therefore, this may not be the most accurate measure of muscle function for these mouse models.

No significant differences were seen for any cohort that underwent rotarod analysis.

\section{Discussion}

As most NM patients with $N E B$ mutations have a compound heterozygous genotype and do not have a severe phenotype, there is a need for an animal model that accurately represents these features. The only murine model to 


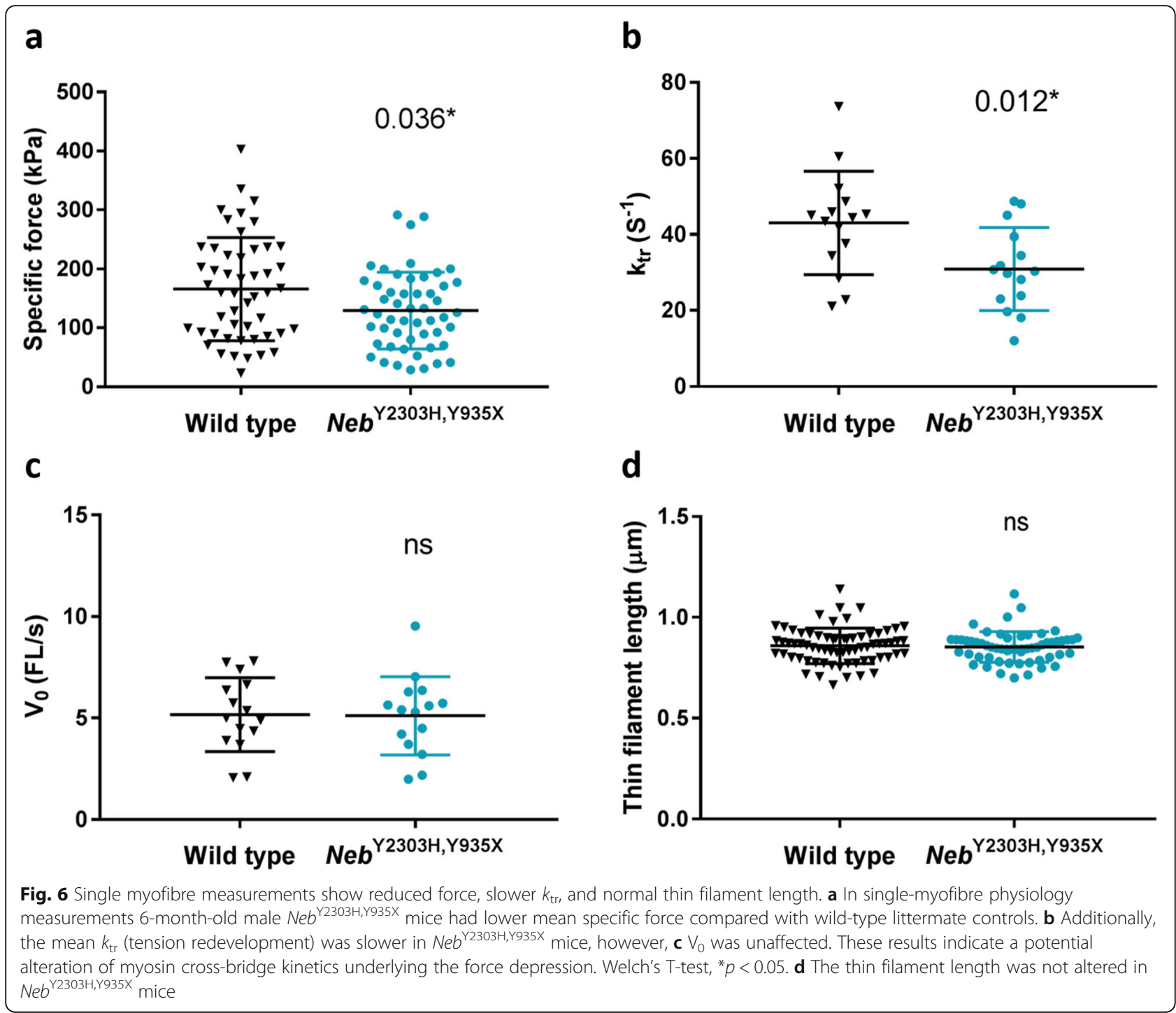

date that has harboured a mutation akin to those found in human patients has been the $N e b^{\Delta \operatorname{exon} 55}$ mouse [61] with homozgyous deletion of exon 55 . However the $N e b^{\Delta \text { exon55 }}$ model had a very severe NM phenotype, with mice exhibiting dramatic growth retardation and death occurring within the first week of life. This phenotype was very different from the observed phenotype of patients with the equivalent homozygous exon 55 deletion [43]. Contrastingly, another murine model with a large deletion of the C-terminus of nebulin, $\mathrm{Neb}^{\Delta \mathrm{SH} 3}$, had no observable disease phenotype [90]. The $\mathrm{Neb}^{\Delta 163-166}$ mouse that lacks both the C-terminal domains, SRC homology 3 domain (SH3) and serine rich region (SRR), had a moderate myopathic phenotype [46]. All other published $\mathrm{Neb}$ murine models have been knockouts (KO) of $\mathrm{Neb}[8,47,89]$ and are not genetically appropriate models for investigation, as a complete absence of nebulin expression has never been identified in a NEB-NM patient [44]. Muscle defects in mice often result in no abnormal phenotype or less severe clinical phenotypes than in humans [15], which complicates developing a mouse model with a milder phenotype. However, to effectively study nebulin function and the pathogenesis of NEB-NM, a model with a longer lifespan is needed. To this end, we have characterised a murine model with a compound heterozygous $\mathrm{Neb}$ mutation genotype.

$N e b^{\mathrm{Y} 2303 \mathrm{H}, \mathrm{Y} 935 \mathrm{X}}$ mice survive to adulthood and in the current study were all sacrificed by 1 year of age, which is equal to approximately 40 years in humans [21]. This finding aligns with the knowledge that most patients with milder forms of NM do not have an obviously shortened life expectancy [73]. NM patients with two truncating, i.e. frameshift or nonsense mutations in constitutively spliced exons $5^{\prime}$ of exon 180 have not been identified, suggesting that a complete loss of nebulin is not compatible with human life. In the case of two truncating mutations being present, either both or at least 
one is in an alternatively spliced exon [44]. The $\mathrm{Neb}^{\mathrm{Y} 935 \mathrm{X}(+/+)}$ mice, with two loss-of-function alleles, are expected to have complete loss of the nebulin protein, and, indeed, the phenotype is early lethal. This is also in line with previous studies using the $\mathrm{Neb}-\mathrm{KO}$ models [8, 89]. The total $N e b$ transcript level was close to normal in the muscles of heterozygous Neb-KO mice [25], despite genetically only having $50 \%$ of Neb. Furthermore, no differences in total protein levels were detected in heterozygous $\mathrm{Neb}-\mathrm{KO}$ mice, suggesting a compensation mechanism in the wild-type nebulin expression. Only $50 \%$ of nebulin RNA was expressed in $\mathrm{Neb}^{\mathrm{Y} 2303 \mathrm{H}, \mathrm{Y} 935 \mathrm{X}}$ mice and all of these transcripts were expected to contain the missense mutation. Expression of low levels of truncated proteins from transcripts escaping the nonsense-mediated decay pathway cannot, however, be excluded. In rare autosomal dominant cases, a truncated nebulin protein seems to act in a dominant-negative way, contributing to the disease phenotype [33]. Despite the lower level of transcript expressed, the total nebulin protein levels were not found to be decreased in the novel mice studied, indicating a compensation at the protein level from the transcript expressed. Lower levels of nebulin have been seen in some, but not all, NM patients and mice $[42,57,61,63]$, suggesting that a reduction in nebulin protein level is not always associated with the NM phenotype. The differences in nebulin levels across NM patients and mouse models indicate another potential pathogenetic mechanism, i.e. the lower protein level may also contribute to the cascade of events leading to NM. As the $N e b^{\mathrm{Y} 2303 \mathrm{H}}$ mice, with homozygous missense mutations, had no clear disease phenotype, a currently unknown additional mechanism must play a role in the pathogenesis of the NM phenotype in the compound heterozygous model.

The missense variant changes a perfectly conserved amino acid (p.Tyr2303His) in one of the known canonical actin-binding sites (SDxxYK) in super repeat eight (S8), which in human nebulin is known to bind actin weakly [39]. It has been hypothesised that a missense change in an actin-binding site is potentially pathogenic [44], and that a mismatch between nebulin and actin may increase susceptibility to proteolysis [62]. It is also possible that a missense variant in a weakly binding repeat could strengthen actin binding, thus disrupting the dynamic movement of the thin filament proteins in muscle contraction. In compound heterozygous NM patients a missense variant in $N E B$ is usually coupled with another, more disruptive mutation [44], as is the case with the $\mathrm{Neb}^{\mathrm{Y} 2303 \mathrm{H}, \mathrm{Y} 935 \mathrm{X}}$ mice. The exact missense change p.Tyr2303His (corresponding to p.Tyr2308His in the human protein, NP_001258137.1) has not been described in patients. However, the tyrosine in question is $100 \%$ conserved, not only across all of the over 200 actin-binding sites in nebulin, but also across species, highlighting its importance. According to our records, there are six cases with a combination of a missense variant affecting the tyrosine in another conserved actin-binding site, coupled with a nonsense, frameshift or a splice site change in the other allele [44]. Five out of six of these patients presented with typical NM, and one out of six with a mild form of NM. In homozygous form, missense variants lead to a different disease entity, distal nebulin myopathy [84]. As many variant combinations are unique to NM families, genotype-phenotype correlations are difficult to establish. To study disease pathogenesis, a model with a combination of a missense and nonsense mutation is ideal for representing the mild to moderate NM phenotype.

Nemaline bodies are the defining pathological feature in the skeletal muscles of NM patients, regardless of genetic cause, although their abundance does not correlate with disease severity $[6,16,72]$. The skeletal muscles of $N e b^{\mathrm{Y} 2303 \mathrm{H}, \mathrm{Y} 935 \mathrm{X}}$ mice exhibit nemaline bodies, thereby confirming that they are a mouse model of $N E B-\mathrm{NM}$ disease. Nemaline bodies were present in $\mathrm{Neb}^{\mathrm{Y} 2303-}$ $\mathrm{H}, \mathrm{Y} 935 \mathrm{X}$ mouse muscles at the age of 4 months, which is the earliest time point studied histologically. Proteins originating from the thin filament or $\mathrm{Z}$ disc are known components of nemaline bodies [86], which is consistent with the presence of filamentous actin and alpha-actinin in the nemaline bodies found in $\mathrm{Neb}^{\mathrm{Y} 2303 \mathrm{H}, \mathrm{Y} 935 \mathrm{X}}$ mice. Variance in distribution of nemaline bodies between skeletal muscles is often seen in NEB-NM patients [78], and they are most abundant in diaphragm, tongue and masseter [23, 35, 50, 53, 79, 82]. Nemaline bodies in $N E B$-NM patients are found in both fast and slow myofibres, but they may only be present in a limited area of the sample [78, 86]. Similarly, in $\mathrm{Neb}^{\mathrm{Y} 2303 \mathrm{H}, \mathrm{Y} 935 \mathrm{X}}$ mice, the aggregates were not evenly distributed within skeletal muscles. In contrast to the majority of $N E B-N M$ patients, nemaline bodies in $\mathrm{Neb}^{\mathrm{Y} 2303 \mathrm{H}, \mathrm{Y} 935 \mathrm{X}}$ mice were preferentially localised in fast, glycolytic fibres (especially in MHCIIB fibres, not found in human limb muscle), whereas no nemaline bodies were found in slow myofibres. This may explain the lower abundance of nemaline bodies in the $\mathrm{Neb}^{\mathrm{Y} 2303 \mathrm{H}, \mathrm{Y} 935 \mathrm{X}}$ muscles with fewer glycolytic myofibres, i.e. soleus and diaphragm. However, it does not explain the absence in the tibialis anterior with the same fibre-type proportions as the extensor digitorum longus (MHCIIB make up $70 \%$ of total muscle fibres [90]). The reason for these differences between $N e b^{\mathrm{Y} 2303 \mathrm{H}, \mathrm{Y} 935 \mathrm{X}}$ mice and $N E B-\mathrm{NM}$ patients remains to be elucidated. Skeletal muscle biopsies from $N E B-N M$ patients often show type I myofibre atrophy or hypotrophy, combined with type I fibre predominance, and type II hypertrophy is occasionally observed [78]. Rare cases with type II atrophy have also been encountered [86].

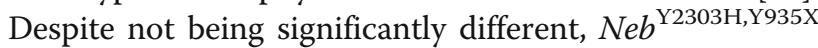


mice showed a trend towards type I fibre predominance in soleus. The same trend towards more oxidative myofibre types in the soleus was also observed in the conditional Neb-KO mouse model [47]. MHCIIA and IIB fibres were significantly smaller, in contrast to most human nemaline patients. Additional signs of skeletal muscle damage in $\mathrm{Neb}^{\mathrm{Y} 2303 \mathrm{H}, \mathrm{Y} 935 \mathrm{X}}$ mice included the presence of split myofibres, internal nuclei and occasional fatty infiltration in quadriceps muscles. This is similar to that seen in NM patients over time [69]. A small number of patients with $N E B$ mutations have been reported to have cores within their skeletal muscles, with some having a combination of a greater number of cores and nemaline bodies (and hence their disorder becoming known as "core-rod myopathy" [86]). Cores have also been identified in distal NM with $N E B$ mutations [76], and in NM patients with RYR1, KBTBD13, CFL2 [86] and ACTA1 mutations [30].

Muscle defects in mice often result in no abnormal phenotype or less severe clinical phenotypes than in humans $[2,9,17,28]$. Several factors may contribute to this, e.g. differences in body mass between human and mouse, bipedal versus quadrupedal movement, the resilient nature of mice, or other factors that differ between mice and humans. A thorough investigation of the in vivo phenotype revealed only minor differences between the mouse strains studied. Indeed, most of the results in the exercise tests remained comparable with wild type, and large sample sizes were required to reach the occasional significance. Overall, the results of the exercise performance were too mild and variable to be used as a reliable measure of the disease phenotype. However, the whole muscle experiments in vitro revealed that the extensor digitorum longus and soleus muscles displayed significant rightward shifts of their force-frequency relationships at lower stimulation frequencies, which is indicative of reduced $\mathrm{Ca}^{2+}$ sensitivity. This has been reported in muscle from patients with $\mathrm{NM}$, including those with NEB-NM [62]. Extensor digitorum longus from $\mathrm{Neb}^{\Delta \mathrm{SH} 3}$ mice also displayed a reduced relative force at lower stimulation frequencies in vitro [90]. Similarly to the $N e b^{\mathrm{Y} 2303 \mathrm{H}, \mathrm{Y} 935 \mathrm{X}}$ mice, this mouse model had no visible phenotype in vivo, despite lacking the entire C-terminal SH3 domain of nebulin, which has been thought to anchor nebulin to the $\mathrm{Z}$ disc, among other roles. In contrast to the $\mathrm{Neb}^{\mathrm{Y} 2303 \mathrm{H}, \mathrm{Y} 935 \mathrm{X}}$ mice, the $N e b^{\Delta \mathrm{SH} 3}$ mice exhibited no histological or ultrastructural changes. As the $N e b^{\mathrm{Y} 2303 \mathrm{H}, \mathrm{Y} 935 \mathrm{X}}$ mice recapitulate several aspects of human NEB-NM, it is an important model for studying nebulin function and disease pathogenesis, despite the mild clinical phenotype.

Whole muscle physiological studies on $\mathrm{Neb}^{\mathrm{Y} 2303 \mathrm{H}, \mathrm{Y9} 53 \mathrm{X}}$ mice indicated increased susceptibility to contractioninduced damage, which potentially occurs when a muscle is stretched as it is contracting (e.g. when people walk downhill). This has also been reported in $\mathrm{Neb}^{\Delta \mathrm{SH} 3}$ mice [90]. Additionally, we found evidence indicating a decrease in stiffness in the soleus muscles from $\mathrm{Neb}^{\mathrm{Y} 2303 \mathrm{H}, \mathrm{Y} 935 \mathrm{X}}$ mice compared with wild-type mice, which is consistent with recent reports showing that stiffness is reduced in slow muscles from nebulin knock-out mice [31]. In contrast to this, our results also showed that extensor digitorum longus muscles from $N e b^{\mathrm{Y} 2303 \mathrm{H}, \mathrm{Y} 935 \mathrm{X}}$ mice are significantly stiffer than those of wild-type mice. This difference in the effects of the combination of the $\mathrm{Neb}^{\mathrm{Y} 2303 \mathrm{H}}$ and $\mathrm{Neb}^{\mathrm{Y} 935 \mathrm{X}}$ variants in fast and slow muscles could be due to differences in the effects of one or both variants on the function of the shorter nebulin isoform found in fast myofibres [67]. An increase in stiffness can also be associated with splitting of myofibres (as often seen over time in NM patients [85]), and were occasionally seen in the extensor digitorum longus and quadriceps of $\mathrm{Neb}^{\mathrm{Y} 2303-}$ $\mathrm{H}, \mathrm{Y935X}$ mice. This may suggest that the increased stiffness occurs predominantly in the fast twitch muscles, as no split myofibres were identified in the soleus. The missense change p.Tyr2303His could potentially affect the interaction between nebulin and actin, resulting in the increased stiffness observed in the extensor digitorum longus muscle of the $\mathrm{Neb}^{\mathrm{Y} 2303 \mathrm{H}, \mathrm{Y} 935 \mathrm{X}}$ mice. Further studies are needed, however, to elucidate the exact mechanism by which stiffness is increased.

Shortened thin filaments have been seen in several of the previous $N e b$ mouse models $[8,47,61,89]$, and in some, but not all $N E B-N M$ patients [87], leading to the hypothesis that the reduction is mutation specific [57, 87]. Shortened thin filaments are thought to contribute to the force deficit observed in the corresponding mouse models [47]. However, as some patients with mutations in $N E B$ have displayed significant force deficits with normal thin filament lengths, other mechanisms must also affect force production [87]. Similarly, single myofibres from $\mathrm{Neb}^{\mathrm{Y} 2303 \mathrm{H}, \mathrm{Y} 935 \mathrm{X}}$ tibialis anterior muscles had lower maximum force production, yet no change in thin filament length. No difference in maximum force was detected at a whole muscle level (extensor digitorum longus and soleus) for $\mathrm{Neb}^{\mathrm{Y} 2303 \mathrm{H}, \mathrm{Y9} 93 \mathrm{X}}$ mice, and thus it is likely that the calcium transient and/or the muscle architecture (e.g. pennation angle, quantity of noncontractile material) are recompensing for the force deficit detected at the myofilament level.

Taken together, our data suggest that the nebulin defects harboured by these mice alter myosin binding to actin (potentially a slower attachment rate), thus disrupting cross-bridge cycling and ultimately perturbing force production. Altered myosin cross-bridge kinetics has frequently been found to underly force depression in NM models [88]. Force generated per cross-bridge, and the number of strongly bound cross-bridges both contribute 
to the force generated at a given overlap between the filaments. Cross-bridge cycling kinetics determine both of these quantifiers by modulating the time spent in the strongly bound state. Chandra and co-workers found that nebulin does not affect the force produced per individual cross-bridge in the Neb-KO mouse model [12]. Our results corroborate this, as decreased time spent by individual myosin molecules in a strongly attached forceproducing conformation was observed in the $\mathrm{Neb}^{\mathrm{Y} 2303-}$ $\mathrm{H}, \mathrm{Y} 935 \mathrm{X}$ mice. These physiological attributes detected in skeletal muscles of $\mathrm{Neb}^{\mathrm{Y} 2303 \mathrm{H}, \mathrm{Y} 935 \mathrm{X}}$ align with previous measurements of samples from NEB-NM patients [57].

\section{Conclusions}

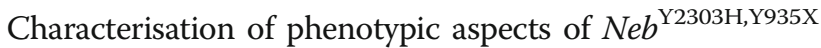
mice with compound heterozygous $N e b$ mutations, like most $N E B$-NM mutations, has determined that they are a suitable murine model of NEB-NM. They exhibit nemaline bodies within their skeletal muscles and have several other histological and physiological parameters resembling NM. These findings make $\mathrm{Neb}^{\mathrm{Y} 2303 \mathrm{H}, \mathrm{Y} 935 \mathrm{X}}$ mice the most appropriate mouse model of $N E B$-NM thus far. Despite the mild in vivo phenotype, the $\mathrm{Neb}^{\mathrm{Y} 2303 \mathrm{H}, \mathrm{Y} 935 \mathrm{X}}$ mice, along with their corresponding parental lines that carry either the missense or the nonsense mutation, will be useful in deciphering nebulin function and the pathogenetic mechanisms of $N E B$-NM. Additionally, they may constitute a good animal model for primary myosin motor dysfunction, and are likely to be valuable for the assessment of potential therapeutic approaches for $N E B-N M$.

\section{Supplementary information}

Supplementary information accompanies this paper at https://doi.org/10. 1186/s40478-020-0893-1.

Additional file 1. Fibre sizes and fibre-type proportions as numbers. 9-month-old female $\mathrm{Neb}^{\mathrm{Y} 2303 \mathrm{H}, \mathrm{Y9} 35 \mathrm{X}}$ mice, mean with standard deviation. Unpaired Mann-Whitney, $n=3,{ }^{*} p<0.05$; ${ }^{* *} p<0.005$; ${ }^{* * *} p<0.0005$;

**** $p<0.0001$.

Additional file 2. Summary of the whole muscle physiology results. a Individual muscle mass, maximum specific force, twitch specific force, maximal rate of force production ( $\mathrm{dF} / \mathrm{dt}$ ), contraction time (time-to-peak), half-relaxation time. Unpaired t-test. b Force frequency, c eccentric damage, $\mathbf{d}$ eccentric peak stretch. Two-way ANOVA (Sidak's multiple comparisons test). Data presented as mean $+/-$ SEM; $n=8$; ${ }^{*} p<0.05 ;{ }^{* *} p<0.005$; ${ }^{* * *} p<0.0005 ;{ }^{* * * *} p<0.0001$

Additional file 3. Bodyweight and gross functional changes of $\mathrm{Neb}^{\mathrm{Y} 2303 \mathrm{H}, \mathrm{Y935X}}, \mathrm{Neb}^{\mathrm{Y935X}}$ and $\mathrm{Neb}^{\mathrm{Y} 2303 \mathrm{H}}$ mice at 6 months of age. a Female $\mathrm{Neb}^{\mathrm{Y} 2303 \mathrm{H}, \mathrm{Y} 935 \mathrm{X}}$ and $\mathrm{Neb}^{\mathrm{Y9} 93 \mathrm{X}}$ mice weighed less $\left(p=0.017^{*}\right.$ and $p=0.014^{*}$, respectively) than wild-type littermate controls. The functional performance of the mice was tested using whole animal in vivo experiments. $\mathbf{b}$ Grip strength testing showed reduced average grip $\left(p=0.013^{*}\right)$ and reduced maximum grip $\left(p=0.0039^{* *}\right)$ for the female Neb ${ }^{\text {Y2303H,Y935X }}$ mice. c Female $\mathrm{Neb}^{\mathrm{Y} 2303 \mathrm{H}, \mathrm{Y} 935 \mathrm{X}}$ mice had impaired performance for three of the four voluntary running wheel measures; distance $\left(p=0.04^{*}\right)$, max speed $\left(p=0.026^{*}\right)$, duration $(p=0.072)$, and average speed $\left(p=0.038^{*}\right)$. However, no significant differences were demonstrated with the rotarod analyses (data not shown), or for the males in any of the functional tests. Mann-Whitney, ${ }^{*} p<0.05$; ${ }^{* *} p<0.005, n=10-22$ for each parameter.

\section{Abbreviations}

BSA: Bovine serum albumin; CSA: Cross-sectional area; dF/dt: Maximum rate of force development; EDL: Extensor digitorum longus; ENU: N-ethyl-Nnitrosourea; $f_{\text {app }}$ : Rate constant for (myosin) attachment; FCS: Foetal calf serum; $g_{\text {app }}$ : Rate constant for (myosin) detachment; H\&E: Haematoxylin and eosin; kb: Kilobase; kDa: Kilodalton; KO: Knock-out; $k_{\mathrm{tr}}$ : Rate of force redevelopment; $L_{0}$ : Optimal muscle length; $\mathrm{MHCl}$ : Myosin heavy chain I (slow); MHCll: Myosin heavy chain II (fast); NEB: Human nebulin gene; Neb: Mouse nebulin gene; NEB-NM: Nebulin related nemaline myopathy; NM: Nemaline myopathy; PBS: Phosphate buffered saline;

PFA: Paraformaldehyde; qRT-PCR: Quantitative reverse-transcriptase PCR: RT: Room temperature; SDH: Succinate dehydrogenase; SH3: SRC homology 3 domain; SOL: Soleus; SRR: Serine rich region; TA: Tibialis anterior;

Tmod: Tropomodulin; $V_{0}$ : Maximum unloaded shortening velocity; WT: Wild type

\section{Acknowledgements}

We sincerely thank the dedicated and professional staff at the Western Australian Government's Animal Resources Centre.

\section{Declarations}

$M L$ receives research support and is on scientific advisory boards for Audentes Therapeutics, Solid Biosciences, and Ichorion Therapeutics, and is a consultant for Dynacure, Valerion Therapeutics, and Wave Life Sciences.

\section{Authors' contributions}

The project was conceived, planned and overseen by KN, KP, JL, CWP and NL. JL, EM and HG collected muscle samples, JL, EM and RH conducted and analysed the histological experiments and immunostaining. Electron microscopy was performed by LG and analysed by LG, ML and CS. Whole muscle physiology experiments were performed and interpreted by $\mathrm{CW}$ and $A B$, and single myofibre experiments by JR and JO. qRT-PCR experiments were performed and analysed by RT, and protein levels assessed by RP and CO. Further assistance in experimental work or writing was provided by GR and JC. JL was the major contributor in writing the article and producing the figures, with the help of all other authors.

Jenni Laitila (JL), Elyshia L. McNamara (EM), Catherine D. Wingate (CW), Hayley Goullee (HG), Jacob A. Ross (JR), Rhonda L. Taylor (RT), Robbert van der Pijl (RP), Lisa M. Griffiths (LG), Rachel Harries (RH), Gina Ravenscroft (GR), Joshua Clayton (JC), Caroline Sewry (CS), Michael W. Lawlor (ML), Coen Ottenheijm (CO), Anthony J. Bakker (AB), Julien Ochala (JO), Nigel G. Laing $(\mathrm{NL})$, Carina Wallgren-Pettersson (CWP), Katarina Pelin (KP), Kristen J. Nowak $(\mathrm{KN})$

\section{Funding}

We gratefully acknowledge research project funding from A Foundation Building Strength for Nemaline Myopathy (KN), and fellowship funding from the Endeavour Scholarships and Fellowships of the Australian Government (Endeavour Research Fellowship BR15-001318; JL), the Sigrid Jusélius Foundation, the Association Francaise contre les Myopathies (18761), the Finska Läkaresällskapet and the Medicinska Understödsföreningen Liv och Hälsa r.f. (JL, KP and CWP), the Australian Research Council (Future Fellowship FT100100734; KN), the Australian National Health and Medical Research Council Fellowship (Principal Research Fellowship APP1117510; NL), the Australian National Health and Medical Research Council Fellowship (Career Development Fellowship APP1122952; GR) and the Medical Research Council UK (MR/N002768/1; JO).

\section{Availability of data and materials}

All data generated or analysed during this study are included in this published article and its supplementary information files.

\section{Ethics approval}

All applicable international, national, and/or institutional guidelines for the care and use of animals were followed. All procedures performed in the studies involving animals were in accordance with the ethical standards of the institution or practice at which the studies were conducted. 


\section{Competing interests}

The authors declare that they have no competing interests.

\section{Author details}

${ }^{1}$ Folkhälsan Institute of Genetics, Folkhälsan Research Center, Biomedicum, Helsinki, Finland. 'Department of Medical and Clinical Genetics, Medicum, University of Helsinki, Helsinki, Finland. ${ }^{3}$ Harry Perkins Institute of Medical Research, QEIl Medical Centre, Nedlands, Western Australia, Australia. ${ }^{4}$ Centre for Medical Research, University of Western Australia, Perth, Australia. ${ }^{5}$ School of Human Sciences, University of Western Australia, Perth, Western Australia, Australia. ${ }^{6}$ Centre for Human and Applied Physiological Sciences / Randall Centre for Cell and Molecular Biophysics, School of Basic and Medical Biosciences, Faculty of Life Sciences and Medicine, King's College London, London, UK. ${ }^{7}$ Department of Cellular and Molecular Medicine, University of Arizona, Tucson, USA. ${ }^{8}$ Department of Neuropathology, PathWest Anatomical Pathology, Nedlands, Western Australia, Australia. ${ }^{9}$ Dubowitz Neuromuscular Centre, Institute of Child Health and Great Ormond Street Hospital, Guilford Street, London, UK. ${ }^{10}$ Wolfson Centre of Inherited Neuromuscular Diseases, RJAH Orthopaedic Hospital, Oswestry, UK. ${ }^{11}$ Division of Pediatric Pathology and Neuroscience Research Center, Medical College of Wisconsin, Milwaukee, USA. ${ }^{12}$ Faculty of Biological and Environmental Sciences, Molecular and Integrative Biosciences Research Programme, University of Helsinki, Helsinki, Finland. ${ }^{13}$ School of Biomedical Sciences, Faculty of Health and Medical Sciences, University of Western Australia, Nedlands, Australia. ${ }^{14}$ Office of Population Health Genomics, Public and Aboriginal Health Division, Western Australian Department of Health, East Perth, Western Australia, Australia.

\section{Received: 11 December 2019 Accepted: 5 February 2020}

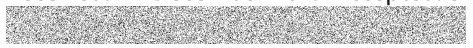

\section{References}

1. Abdalla E, Ravenscroft G, Zayed L, Beecroft SJ, Laing NG (2017) Lethal multiple pterygium syndrome: a severe phenotype associated with a novel mutation in the nebulin gene. Neuromuscul Disord 27:537-541. https://doi. org/10.1016/j.nmd.2017.01.013

2. Acakpo-Satchivi LJR, Edelmann W, Sartorius C, Lu BD, Wahr PA, Watkins SC, Metzger JM, Leinwand L, Kucherlapati R (1997) Growth and muscle defects in mice lacking adult myosin heavy chain genes. J Cell Biol 139:1219-1229. https://doi.org/10.1083/jcb.139.5.1219

3. Agbulut O, Destombes J, Thiesson D, Butler-Browne G (2000) Age-related appearance of tubular aggregates in the skeletal muscle of almost all male inbred mice. Histochem Cell Biol 114:477-481

4. Agrawal PB, Greenleaf RS, Tomczak KK, Lehtokari V-L, Wallgren-Pettersson C, Wallefeld W, Laing NG, Darras BT, Maciver SK, Dormitzer PR, Beggs AH (2007) Nemaline myopathy with minicores caused by mutation of the CFL2 gene encoding the skeletal muscle actin-binding protein, cofilin-2. Am J Hum Genet 80:162-167. https://doi.org/10.1086/510402

5. Andrews TD, Whittle B, Field MA, Balakishnan B, Zhang Y, Shao Y, Cho V, Kirk M, Singh M, Xia Y, Hager J, Winslade S, Sjollema G, Beutler B, Enders A, Goodnow CC (2012) Massively parallel sequencing of the mouse exome to accurately identify rare, induced mutations: an immediate source for thousands of new mouse models. Open Biol 2:120061-120061. https://doi. org/10.1098/rsob.120061

6. Arts WF, Bethlem J, Dingemans KP, Eriksson AW (1978) Investigations on the inheritance of nemaline myopathy. Arch Neurol 35:72-77. https://doi.org/10. 1001/archneur.1978.00500260010002

7. Bakker AJ, Cully TR, Wingate CD, Barclay CJ, Launikonis BS (2017) Doublet stimulation increases $\mathrm{Ca} 2+$ binding to troponin $\mathrm{C}$ to ensure rapid force development in skeletal muscle. J Gen Physiol 149:323-334. https://doi.org/ 10.1085/jgp.201611727

8. Bang ML, Li X, Littlefield R, Bremner S, Thor A, Knowlton KU, Lieber RL, Chen $J$ (2006) Nebulin-deficient mice exhibit shorter thin filament lengths and reduced contractile function in skeletal muscle. J Cell Biol 173:905-916. https://doi.org/10.1083/jcb.200603119

9. Bonaldo P, Braghetta P, Zanetti M, Piccolo S, Volpin D, Bressan GM (1998) Collagen VI deficiency induces early onset myopathy in the mouse: an animal model for Bethlem myopathy. Hum Mol Genet 7:2135-2140. https:// doi.org/10.1093/hmg/7.13.2135

10. Brenner B, Eisenberg E (1986) Rate of force generation in muscle: correlation with actomyosin ATPase activity in solution. Proc Natl Acad Sci 83:35423546. https://doi.org/10.1073/pnas.83.10.3542
11. Burkholder TJ, Fingado B, Baron S, Lieber RL (1994) Relationship between muscle fiber types and sizes and muscle architectural properties in the mouse hindlimb. J Morphol 221:177-190. https://doi.org/10.1002/jmor. 1052210207

12. Chandra M, Manidi R, Ford S, Hidalgo C, Witt C, Ottenheijm C, Labeit S, Granzier H (2009) Nebulin alters cross-bridge cycling kinetics and increases thin filament activation. A novel mechanism for increasing tension and reducing tension cost. J Biol Chem 284:30889-30896. https://doi.org/10. 1074/jbc.M109.049718

13. Chu M, Gregorio CC, Pappas CT (2016) Nebulin, a multi-functional giant J Exp Biol 219:146-152. https://doi.org/10.1242/jeb.126383

14. Conen PE, Murphy EG, Donohue WL (1963) Light and electron microscopic studies of "myogranules" in child with hypotonia and muscle weakness. Can Med Assoc J 89:983-986. https://doi.org/10.1001/jama.1963.03710100122083

15. Corbett MA, Robinson CS, Dunglison GF, Yang N, Joya JE, Stewart AW, Schnell C, Gunning PW, North KN, Hardeman EC (2001) A mutation in alpha-tropomyosin slow affects muscle strength, maturation and hypertrophy in a mouse model for nemaline myopathy. Hum Mol Genet 10: 317-328. https://doi.org/10.1093/hmg/10.4.317

16. Dahl DS, Klutzow FW (1974) Congenital rod disease: further evidence of innervational abnormalities as the basis for the clinicopathologic features. J Neurol Sci 23:371-385. https://doi.org/10.1016/0022-510X(74)90155-5

17. Dangain J, Vrbova G (1984) Muscle development in mdx mutant mice. Muscle Nerve 7:700-704. https://doi.org/10.1002/mus.880070903

18. Donner K, Ollikainen M, Ridanpää M, Christen H-J, Goebel HH, de Visser M Pelin K, Wallgren-Pettersson C (2002) Mutations in the $\beta$-tropomyosin (TPM2) gene - a rare cause of nemaline myopathy. Neuromuscul Disord 12: 151-158. https://doi.org/10.1016/S0960-8966(01)00252-8

19. Donner K, Sandbacka M, Lehtokari V-L, Wallgren-Pettersson C, Pelin K (2004) Complete genomic structure of the human nebulin gene and identification of alternatively spliced transcripts. Eur J Hum Genet 12:744-751. https://doi. org/10.1038/sj.ejhg.5201242

20. Dubowitz V, Sewry CA, Oldfors A (2013) Muscle biopsy: a practical approach, 4th edn. Saunders-Elsevier, Philadelphia

21. Dutta S, Sengupta P (2016) Men and mice: relating their ages. Life Sci 152 244-248. https://doi.org/10.1016/J.LFS.2015.10.025

22. Edman KA (1979) The velocity of unloaded shortening and its relation to sarcomere length and isometric force in vertebrate muscle fibres. J Physiol 291:143-159. https://doi.org/10.1113/jphysiol.1979.sp012804

23. Eeg-Olofsson O, Henriksson KG, Thorneil LE, Wesström G (1983) Early infant death in nemaline (rod) myopathy. Brain Dev 5:53-57. https://doi.org/10. 1016/S0387-7604(83)80011-4

24. Frontera WR, Larsson $L$ (1997) Contractile studies of single human skeletal muscle fibers: a comparison of different muscles, permeabilization procedures, and storage techniques. Muscle Nerve 20:948-952. https://doi. org/10.1002/(SICI)1097-4598(199708)20:8<948::AID-MUS3>3.0.CO;2-6

25. Gineste C, De Winter JM, Kohl C, Witt CC, Giannesini B, Brohm K, Le Fur Y, Gretz N, Vilmen C, Pecchi E, Jubeau M, Cozzone PJ, Stienen GJM, Granzier H, Labeit S, Ottenheijm CAC, Bendahan D, Gondin J (2013) In vivo and in vitro investigations of heterozygous nebulin knock-out mice disclose a mild skeletal muscle phenotype. Neuromuscul Disord 23:357-369. https://doi.org/ 10.1016/j.nmd.2012.12.011

26. Gokhin DS, Lewis RA, McKeown CR, Nowak RB, Kim NE, Littlefield RS, Lieber RL, Fowler VM (2010) Tropomodulin isoforms regulate thin filament pointed-end capping and skeletal muscle physiology. J Cell Biol 189:95-109. https://doi.org/10.1083/jcb.201001125

27. Gupta VA, Ravenscroft G, Shaheen R, Todd EJ, Swanson LC, Shiina M, Ogata K, Hsu C, Clarke NF, Darras BT, Farrar MA, Hashem A, Manton ND, Muntoni F, North KN, Sandaradura SA, Nishino I, Hayashi YK, Sewry CA, Thompson EM, Yau KS, Brownstein CA, Yu TW, Allcock RJN, Davis MR, Wallgren-Pettersson C, Matsumoto N, Alkuraya FS, Laing NG, Beggs AH (2013) Identification of KLHL41 mutations implicates BTB-Kelch-mediated ubiquitination as an alternate pathway to myofibrillar disruption in nemaline myopathy. Am J Hum Genet 93:1108-1117. https://doi.org/10.1016/j.ajhg.2013.10.020

28. Jansen G, Groenen PJTA, Bächner D, Jap PH, Coerwinkel M, Oerlemans F, Van Den Broek W, Gohlsch B, Pette D, Plomp JJ, Molenaar PC, Nederhoff MGJ, Van Echteld CJA, Dekker M, Berns A, Hameister H, Wieringa B (1996) Abnormal myotonic dystrophy protein kinase levels produce only mild myopathy in mice. Nat Genet 13:316-324. https://doi.org/10.1038/ng0796-316

29. Johnston JJ, Kelley Rl, Crawford TO, Morton DH, Agarwala R, Koch T, Schäffer AA, Francomano CA, Biesecker LG (2000) A novel nemaline 
myopathy in the Amish caused by a mutation in troponin T1. Am J Hum Genet 67:814-821. https://doi.org/10.1086/303089

30. Jungbluth $H$, Sewry C, Brown S, Nowak K, Laing N, Wallgren-Pettersson C, Pelin K, Manzur A, Mercuri E, Dubowitz V, Muntoni F (2001) Mild phenotype of nemaline myopathy with sleep hypoventilation due to a mutation in the skeletal muscle a-actin (ACTA1) gene. Neuromuscul Disord 11:35-40. https://doi.org/10.1016/S0960-8966(00)00167-X

31. Kawai M, Karam TS, Kolb J, Wang L, Granzier HL (2018) Nebulin increases thin filament stiffness and force per cross-bridge in slow-twitch soleus muscle fibers. J Gen Physiol 150:1510-1522. https://doi.org/10.1085/jgp.201812104

32. Kiiski K, Lehtokari V, Löytynoja A, Ahlstén L, Laitila J, Wallgren-Pettersson C, Pelin K (2016) A recurrent copy number variation of the NEB triplicate region: only revealed by the targeted nemaline myopathy CGH array. Eur J Hum Genet 24:574-580. https://doi.org/10.1038/ejhg.2015.166

33. Kiiski KJ, Lehtokari VL, Vihola AK, Laitila JM, Huovinen $S$, Sagath LJ, Evilä $A E_{\text {, }}$ Paetau AE, Sewry CA, Hackman PB, Pelin KB, Wallgren-Pettersson C, Udd B (2019) Dominantly inherited distal nemaline/cap myopathy caused by a large deletion in the nebulin gene. Neuromuscul Disord 29:97-107. https:// doi.org/10.1016/j.nmd.2018.12.007

34. Kiss B, Lee E-J, Ma W, Li FW, Tonino P, Mijailovich SM, Irving TC, Granzier HL (2018) Nebulin stiffens the thin filament and augments cross-bridge interaction in skeletal muscle. Proc Natl Acad Sci 115:10369-10374. https:// doi.org/10.1073/pnas.1804726115

35. Kolin IS (1967) Nemaline myopathy: a fatal case. Am J Dis Child 114:95-100. https://doi.org/10.1001/archpedi.1967.02090220101019

36. Labeit S, Kolmerer B (1995) The complete primary structure of human nebulin and its correlation to muscle structure. J Mol Biol 248:308-315. https://doi.org/10.1016/S0022-2836(95)80052-2

37. Laing NG, Wilton SD, Akkari PA, Dorosz S, Boundy K, Kneebone C, Blumbergs P, White S, Watkins H, Love DR, Haan E (1995) A mutation in the a tropomyosin gene TPM3 associated with autosomal dominant nemaline myopathy. Nat Genet 9:75-79. https://doi.org/10.1038/ng0195-75

38. Laitila J, Hanif M, Paetau A, Hujanen S, Keto J, Somervuo P, Huovinen S, Udd B, Wallgren-Pettersson C, Auvinen P, Hackman P, Pelin K (2012) Expression of multiple nebulin isoforms in human skeletal muscle and brain. Muscle Nerve 46:730-737. https://doi.org/10.1002/mus.23380

39. Laitila J, Lehtonen J, Lehtokari V-L, Sagath L, Wallgren-Pettersson C, Grönholm M, Pelin K (2019) A nebulin super-repeat panel reveals stronger actin binding toward the ends of the super-repeat region. Muscle Nerve 59: 116-121. https://doi.org/10.1002/mus.26350

40. Lam LT, Holt I, Laitila J, Hanif M, Pelin K, Wallgren-Pettersson C, Sewry CA, Morris GE (2018) Two alternatively-spliced human nebulin isoforms with either exon 143 or exon 144 and their developmental regulation. Sci Rep 8: 15728. https://doi.org/10.1038/s41598-018-33281-6

41. Lavin T, Song Y, Bakker AJ, McLean CJ, Macdonald WA, Noble PB, Berry CA, Pillow JJ, Pinniger GJ (2013) Developmental changes in diaphragm muscle function in the preterm and postnatal lamb. Pediatr Pulmonol 48:640-648. https://doi.org/10.1002/ppul.22762

42. Lawlor MW, Ottenheijm CA, Lehtokari V-L, Cho K, Pelin K, WallgrenPettersson C, Granzier H, Beggs AH (2011) Novel mutations in NEB cause abnormal nebulin expression and markedly impaired muscle force generation in severe nemaline myopathy. Skelet Muscle 1:1-12. https://doi. org/10.1186/2044-5040-1-23

43. Lehtokari VL, Greenleaf RS, DeChene ET, Kellinsalmi M, Pelin K, Laing NG, Beggs AH, Wallgren-Pettersson C (2009) The exon 55 deletion in the nebulin gene - one single founder mutation with world-wide occurrence. Neuromuscul Disord 19:179-181. https://doi.org/10.1016/j.nmd.2008.12.001

44. Lehtokari VL, Kiiski K, Sandaradura SA, Laporte J, Repo P, Frey JA, Donner K, Marttila M, Saunders C, Barth PG, den Dunnen JT, Beggs AH, Clarke NF, North KN, Laing NG, Romero NB, Winder TL, Pelin K, Wallgren-Pettersson C (2014) Mutation update: the spectra of nebulin variants and associated myopathies. Hum Mutat 35:1418-1426. https://doi.org/10.1002/humu.22693

45. Lehtokari VL, Pelin K, Herczegfalvi A, Karcagi V, Pouget J, Franques J, Pellissier JF, Figarella-Branger D, von der Hagen M, Huebner A, Schoser B, Lochmüller H, Wallgren-Pettersson C (2011) Nemaline myopathy caused by mutations in the nebulin gene may present as a distal myopathy. Neuromuscul Disord 21:556-562. https://doi.org/10.1016/j.nmd.2011.05.012

46. Li F, Barton ER, Granzier H (2019) Deleting nebulin's C-terminus reveals its importance to sarcomeric structure and function and is sufficient to invoke nemaline myopathy. Hum Mol Genet 28:1709-1725. https://doi.org/10.1093/ $\mathrm{hmg} / \mathrm{ddz} 016$
47. Li F, Buck D, De Winter J, Kolb J, Meng H, Birch C, Slater R, Escobar YN, Smith JE, Yang L, Konhilas J, Lawlor MW, Ottenheijm C, Granzier HL (2015) Nebulin deficiency in adult muscle causes sarcomere defects and muscletype-dependent changes in trophicity: novel insights in nemaline myopathy. Hum Mol Genet 24:5219-5233. https://doi.org/10.1093/hmg/ ddv243

48. Lindqvist J, Cheng AJ, Renaud G, Hardeman EC, Ochala J (2013) Distinct underlying mechanisms of limb and respiratory muscle Fiber weaknesses in Nemaline myopathy. J Neuropathol Exp Neurol 72:472-481. https://doi.org/ 10.1097/NEN.0b013e318293b1cc

49. Lindqvist J, Levy Y, Pati-Alam A, Hardeman EC, Gregorevic P, Ochala J (2016) Modulating myosin restores muscle function in a mouse model of nemaline myopathy. Ann Neurol 79:717-725. https://doi.org/10.1002/ana.24619

50. Matsuo T, Tashiro T, Ikeda T, Tsujihata M, Shimomura C (1982) Fatal neonata nemaline myopathy. Pathol Int 32:907-916. https://doi.org/10.1111/j.14401827.1982.tb03205.x

51. Mendez J, Keys A (1960) Density and composition of mammalian muscle. Metabolism 9:184-188

52. Miyatake S, Mitsuhashi S, Hayashi YK, Purevjav E, Nishikawa A, Koshimizu E, Suzuki M, Yatabe K, Tanaka Y, Ogata K, Kuru S, Shiina M, Tsurusaki Y, Nakashima M, Mizuguchi T, Miyake N, Saitsu H, Ogata K, Kawai M, Towbin J, Nonaka I, Nishino I, Matsumoto N (2017) Biallelic mutations in MYPN, encoding myopalladin, are associated with childhood-onset, slowly progressive nemaline myopathy. Am J Hum Genet 100:169-178. https://doi. org/10.1016/j.ajhg.2016.11.017

53. Norton P, Ellison P, Sulaiman AR, Harb J (1983) Nemaline myopathy in the neonate. Neurology 33:351-356. https://doi.org/10.1212/WNL.33.3.351

54. Nowak KJ, Ravenscroft G, Jackaman C, Filipovska A, Davies SM, Lim EM, Squire SE, Potter AC, Baker E, Clément S, Sewry CA, Fabian V, Crawford K, Lessard JL, Griffiths LM, Papadimitriou JM, Shen Y, Morahan G, Bakker AJ, Davies KE, Laing NG (2009) Rescue of skeletal muscle a-actin-null mice by cardiac (fetal) a-actin. J Cell Biol 185:903-915. https://doi.org/10.1083/jcb. 200812132

55. Nowak K, Wattanasirichaigoon D, Goebel HH, Wilce M, Pelin K, Donner K, Jacob RL, Hübner C, Oexle K, Anderson JR, Verity CM, North KN, lannaccone ST, Müller CR, Nürnberg P, Muntoni F, Sewry C, Hughes I, Sutphen R, Lacson AG, Swoboda KJ, Vigneron J, Wallgren-Pettersson C, Beggs AH, Laing NG (1999) Mutations in the skeletal muscle a-actin gene in patients with actin myopathy and nemaline myopathy. Nat Genet 23:208-212. https://doi.org/ 10.1038/13837

56. Ochala J, Gokhin DS, Pénisson-Besnier I, Quijano-Roy S, Monnier N, Lunardi J, Romero NB, Fowler VM (2012) Congenital myopathy-causing tropomyosin mutations induce thin filament dysfunction via distinct physiological mechanisms. Hum Mol Genet 21:4473-4485. https://doi.org/10.1093/hmg/ dds 289

57. Ochala J, Lehtokari V-L, Iwamoto H, Li M, Feng H-Z, Jin J-P, Yagi N, Wallgren-Pettersson C, Penisson-Besnier I, Larsson L (2011) Disrupted myosin cross-bridge cycling kinetics triggers muscle weakness in nebulinrelated myopathy. FASEB J 25:1903-1913. https://doi.org/10.1096/fj.10176727

58. Ochala J, Li M, Ohlsson M, Oldfors A, Larsson L (2008) Defective regulation of contractile function in muscle fibres carrying an E41K $\beta$-tropomyosin mutation. J Physiol 586:2993-3004. https://doi.org/10.1113/jphysiol.2008. 153650

59. Ochala J, Li M, Tajsharghi H, Kimber E, Tulinius M, Oldfors A, Larsson L (2007) Effects of a R133W $\beta$-tropomyosin mutation on regulation of muscle contraction in single human muscle fibres. J Physiol 581:1283-1292. https:// doi.org/10.1113/jphysiol.2007.129759

60. Ochala J, Ravenscroft G, Laing NG, Nowak KJ (2012) Nemaline myopathyrelated skeletal muscle a-actin (ACTA1) mutation, Asp286Gly, prevents proper strong myosin binding and triggers muscle weakness. PLoS One 7: e45923. https://doi.org/10.1371/journal.pone.0045923

61. Ottenheijm CAC, Buck D, De Winter JM, Ferrara C, Piroddi N, Tesi C, Jasper JR, Malik FI, Meng H, Stienen GJM, Beggs AH, Labeit S, Poggesi C, Lawlor MW, Granzier H (2013) Deleting exon 55 from the nebulin gene induces severe muscle weakness in a mouse model for nemaline myopathy. Brain 136:1718-1731. https://doi.org/10.1093/brain/awt113

62. Ottenheijm CAC, Hooijman P, DeChene ET, Stienen GJ, Beggs AH, Granzier $H$ (2010) Altered myofilament function depresses force generation in patients with nebulin-based nemaline myopathy (NEM2). J Struct Biol 170: 334-343. https://doi.org/10.1016/j.jsb.2009.11.013 
63. Ottenheijm CAC, Witt CC, Stienen GJ, Labeit S, Beggs AH, Granzier H (2009) Thin filament length dysregulation contributes to muscle weakness in nemaline myopathy patients with nebulin deficiency. Hum Mol Genet 18: 2359-2369. https://doi.org/10.1093/hmg/ddp168

64. Pelin K, Hilpelä P, Donner K, Sewry C, Akkari PA, Wilton SD, Wattanasirichaigoon D, Bang ML, Centner T, Hanefeld F, Odent S, Fardeau M, Urtizberea JA, Muntoni F, Dubowitz V, Beggs AH, Laing NG, Labeit S, de la Chapelle A, Wallgren-Pettersson C (1999) Mutations in the nebulin gene associated with autosomal recessive nemaline myopathy. Proc Natl Acad Sci U S A 96:2305-2310. https://doi.org/10.1073/pnas.96.5.2305

65. Piga D, Magri F, Ronchi D, Corti S, Cassandrini D, Mercuri E, Tasca G, Bertini E, Fattori F, Toscano A, Messina S, Moroni I, Mora M, Moggio M, Colombo I, Giugliano T, Pane M, Fiorillo C, D’Amico A, Bruno C, Nigro V, Bresolin N, Comi G Pietro (2016) New mutations in NEB gene discovered by targeted next-generation sequencing in nemaline myopathy italian patients. J Mol Neurosci 59:351-359. doi: https://doi.org/10.1007/s12031-016-0739-2

66. van der Pijl R, Strom J, Conijn S, Lindqvist J, Labeit S, Granzier H, Ottenheijm C (2018) Titin-based mechanosensing modulates muscle hypertrophy. J Cachexia Sarcopenia Muscle 9:947-961. https://doi.org/10.1002/jcsm.12319

67. Prado LG, Makarenko I, Andresen C, Krüger M, Opitz CA, Linke WA (2005) Isoform diversity of Giant proteins in relation to passive and active contractile properties of rabbit skeletal muscles. J Gen Physiol 126:461-480. https://doi.org/10.1085/jgp.200509364

68. Ramsey KA, Bakker AJ, Pinniger GJ (2010) Fiber-type dependence of stretchinduced force enhancement in rat skeletal muscle. Muscle Nerve 42:769777. https://doi.org/10.1002/mus.21744

69. Ravenscroft G, Miyatake S, Lehtokari V-L, Todd EJ, Vornanen P, Yau KS, Hayashi YK, Miyake N, Tsurusaki Y, Doi H, Saitsu H, Osaka H, Yamashita S, Ohya T, Sakamoto Y, Koshimizu E, Imamura S, Yamashita M, Ogata K, Shiina M, BrysonRichardson RJ, Vaz R, Ceyhan O, Brownstein CA, Swanson LC, Monnot S, Romero NB, Amthor H, Kresoje N, Sivadorai P, Kiraly-Borri C, Haliloglu G, Talim B, Orhan D, Kale G, Charles AK, Fabian VA, Davis MR, Lammens M, Sewry CA, Manzur A, Muntoni F, Clarke NF, North KN, Bertini E, Nevo Y, Willichowski E, Silberg IE, Topaloglu H, Beggs AH, Allcock RJN, Nishino I, Wallgren-Pettersson C, Matsumoto N, Laing NG (2013) Mutations in KLHL40 are a frequent cause of severe autosomal-recessive nemaline myopathy. Am J Hum Genet 93:6-18. https://doi.org/10.1016/j.ajhg.2013.05.004

70. Regnier M, Martyn DA, Chase PB (1998) Calcium regulation of tension redevelopment kinetics with 2-deoxy-ATP or low [ATP] in rabbit skeletal muscle. Biophys J 74:2005-2015. https://doi.org/10.1016/S00063495(98)77907-X

71. Romero NB, Lehtokari V-L, Quijano-Roy S, Monnier N, Claeys KG, Carlier RY, Pellegrini N, Orlikowski D, Barois A, Laing NG, Lunardi J, Fardeau M, Pelin K Wallgren-Pettersson C (2009) Core-rod myopathy caused by mutations in the nebulin gene. Neurology 73:1159-1161. https://doi.org/10.1212/WNL. 0b013e3181bacf45

72. Ryan MM, Ilkovski B, Strickland CD, Schnell C, Sanoudou D, Midgett C, Houston R, Muirhead D, Dennett X, Shield LK, De Girolami U, lannaccone ST, Laing NG, North KN, Beggs AH (2003) Clinical course correlates poorly with muscle pathology in nemaline myopathy. Neurology 60:665-673. https:// doi.org/10.1212/01.WNL.0000046585.81304.BC

73. Ryan MM, Schnell C, Strickland CD, Shield LK, Morgan G, lannaccone ST, Laing NG, Beggs AH, North KN (2001) Nemaline myopathy: a clinical study of 143 cases. Ann Neurol 50:312-320. https://doi.org/10.1002/ana.1080

74. Sambuughin N, Yau KS, Olivé M, Duff RM, Bayarsaikhan M, Lu S, GonzalezMera L, Sivadorai P, Nowak KJ, Ravenscroft G, Mastaglia FL, North KN, Ilkovski B, Kremer H, Lammens M, Van Engelen BGM, Fabian V, Lamont $P$, Davis MR, Laing NG, Goldfarb LG (2010) Dominant mutations in KBTBD13, a member of the BTB/Kelch family, cause nemaline myopathy with cores. Am J Hum Genet 87:842-847

75. Sandaradura SA, Bournazos A, Mallawaarachchi A, Cummings BB, Waddell LB, Jones KJ, Troedson C, Sudarsanam A, Nash BM, Peters GB, Algar EM, MacArthur DG, North KN, Brammah S, Charlton A, Laing NG, Wilson MJ, Davis MR, Cooper ST (2018) Nemaline myopathy and distal arthrogryposis associated with an autosomal recessive TNNT3 splice variant. Hum Mutat 39:383-388. https://doi.org/10.1002/humu.23385

76. Scoto M, Cullup T, Cirak S, Yau S, Manzur AY, Feng L, Jacques TS, Anderson G, Abbs S, Sewry C, Jungbluth H, Muntoni F (2013) Nebulin (NEB) mutations in a childhood onset distal myopathy with rods and cores uncovered by next generation sequencing. Eur J Hum Genet 21:1249-1252. https://doi. org/10.1038/ejhg.2013.31
77. Sewry CA, Laitila JM, Wallgren-Pettersson C (2019) Nemaline myopathies: a current view. J Muscle Res Cell Motil 40:111-126. https://doi.org/10.1007/ s10974-019-09519-9

78. Sewry CA, Wallgren-Pettersson C (2017) Myopathology in congenital myopathies. Neuropathol Appl Neurobiol 43:5-23. https://doi.org/10.1111/ nan.12369

79. Shafiq SA, Dubowitz V, De C. Peterson H, Milhorat AT (1967) Nemaline myopathy: report of a fatal case, with histochemical and electron microscopic studies. Brain 90:817-828. doi: https://doi.org/10.1093/brain/90. 4.817

80. Shy GM, Engel WK, Somers JE, Wanko T (1963) Nemaline myopathy: a new congenital myopathy. Brain 86:793-810. https://doi.org/10.1093/brain/86.4.793

81. Tonino P, Pappas CT, Hudson BD, Labeit S, Gregorio CC, Granzier H (2010) Reduced myofibrillar connectivity and increased Z-disk width in nebulindeficient skeletal muscle. J Cell Sci 123:384-391. https://doi.org/10.1242/jcs. 042234

82. Tsujihata M, Shimomura C, Yoshimura T, Sato A, Ogawa T, Tsuji Y, Nagataki S, Matsuo T (1983) Fatal neonatal nemaline myopathy: a case report. J Neurol Neurosurg Psychiatry 46:856-859. https://doi.org/10.1136/jnnp.46.9.856

83. Wallgren-Pettersson C, Jasani B, Newman GR, Morris GE, Jones $S$, Singhrao $S$, Clarke A, Virtanen I, Holmberg C, Rapola J (1995) Alpha-actinin in nemaline bodies in congenital nemaline myopathy: immunological confirmation by light and electron microscopy. Neuromuscul Disord 5:93-104. https://doi. org/10.1016/0960-8966(94)00035-8

84. Wallgren-Pettersson C, Lehtokari V-L, Kalimo H, Paetau A, Nuutinen $E$, Hackman P, Sewry C, Pelin K, Udd B (2007) Distal myopathy caused by homozygous missense mutations in the nebulin gene. Brain 130:1465-1476. https://doi.org/10.1093/brain/awm094

85. Wallgren-Pettersson C, Rapola J, Donner M (1988) Pathology of congenital nemaline myopathy. A follow-up study. J Neurol Sci 83:243-257. https://doi. org/10.1016/0022-510X(88)90072-X

86. Wallgren-Pettersson C, Sewry CA, Nowak KJ, Laing NG (2011) Nemaline myopathies. Semin Pediatr Neurol 18:230-238. https://doi.org/10.1016/j. spen.2011.10.004

87. De Winter JM, Joureau B, Lee EJ, Kiss B, Yuen M, Gupta VA, Pappas CT, Gregorio CC, Stienen GJM, Edvardson S, Wallgren-Pettersson C, Lehtokari VL, Pelin K, Malfatti E, Romero NB, Van Engelen BG, Voermans NC, Donkervoort S, Bönnemann CG, Clarke NF, Beggs AH, Granzier H, Ottenheijm CAC (2016) Mutation-specific effects on thin filament length in thin filament myopathy. Ann Neurol 79:959-969. https://doi.org/10.1002/ana.24654

88. De Winter JM, Ottenheijm CAC (2017) Sarcomere dysfunction in nemaline myopathy. J Neuromuscul Dis 4:99-113. https://doi.org/10.3233/JND-160200

89. Witt CC, Burkart C, Labeit D, McNabb M, Wu Y, Granzier H, Labeit S (2006) Nebulin regulates thin filament length, contractility, and Z-disk structure in vivo. EMBO J 25:3843-3855. https://doi.org/10.1038/sj.emboj.7601242

90. Yamamoto DL, Vitiello C, Zhang J, Gokhin DS, Castaldi A, Coulis G, Piaser F, Filomena MC, Eggenhuizen PJ, Kunderfranco P, Camerini S, Takano K, Endo T, Crescenzi M, Luther PKL, Lieber RL, Chen J, Bang M-L (2013) The nebulin $\mathrm{SH} 3$ domain is dispensable for normal skeletal muscle structure but is required for effective active load bearing in mouse. J Cell Sci 126:54775489. https://doi.org/10.1242/jcs.137026

91. Yuen M, Sandaradura SA, Dowling JJ, Kostyukova AS, Moroz N, Quinlan KG, Lehtokari V-L, Ravenscroft G, Todd EJ, Ceyhan-Birsoy O, Gokhin DS, Maluenda J, Lek M, Nolent F, Pappas CT, Novak SM, D'Amico A, Malfatti E, Thomas BP, Gabriel SB, Gupta N, Daly MJ, Ilkovski B, Houweling PJ, Davidson AE, Swanson LC, Brownstein CA, Gupta VA, Medne L, Shannon P, Martin N, Bick DP, Flisberg A, Holmberg E, Van den Bergh $P$, Lapunzina $P$, Waddell LB, Sloboda DD, Bertini E, Chitayat D, Telfer WR, Laquerrière A, Gregorio CC, Ottenheijm CAC, Bönnemann CG, Pelin K, Beggs AH, Hayashi YK, Romero NB, Laing NG, Nishino I, Wallgren-Pettersson C, Melki J, Fowler VM, MacArthur DG, North KN, Clarke NF (2014) Leiomodin-3 dysfunction results in thin filament disorganization and nemaline myopathy. J Clin Invest 124: 4693-4708. https://doi.org/10.1172/JCl75199

\section{Publisher's Note}

Springer Nature remains neutral with regard to jurisdictional claims in published maps and institutional affiliations. 